\title{
Dynamics and Structure of the European Bison Population in the Białowieza Primeval Forest
}

\author{
Zbigniew A. KRASIŃSKI
}

Krasiński Z. A., 1978: Dynamics and structure of the European bison population in the Bialowieża Primeval Forest. Acta theriol., 23, 1: 3-48 [With 9 Tables, 19 Figs. \& P'ates I-II].

The paper discusses population dynamics, sex and age structure, group composition and size, density and spatial structure of a freeliving population of European bison Bison bonasus (L innaeus, 1758) in the Białowieża Primeval Forest. The study covers the period from the start of free breeding in 1952 up to the end in 1973. From 1968-1970 detailed studies were made on the population formed by that time with a total of 2400 observations. The birth coefficient for the period from 1960-1973 averaged $18.5 \%$. The high fecundity coetficient $(70 \%)$ during the initial period of the herd's development dropped $(54 \%)$ during the final study years. Sex ratio at birth did not differ significantly from 1:1 with 316 (161 males, 155 females) calves born. Mortality coefficient was low (3\%). Significantly highe: mortality was observed among males than females. Maximum mortality was found in the group of calves up to one year old $(23 \%)$. The area in which the European bison herd lived enlarged with increase in population numbers up to 1966, after which anly density rose. Habitat preferences influenced distribution of groups of bison during the summer period, the animals most often wandering in mixed deciduous forest $(24 \%$ of encounters) and deciduous forest $(18.5 \%)$, and least often in coniferous forests $(2 \%)$. Feeding bison were often encountered in clearings, meadows and cultivated fields ( $47 \%$ of all encounters). Mixed groups consisting of bison of both sexes in different age classes and bull groups were distinguished. The composition of mixed groups altered depending on the season. During the rutting period (Aug.-Sept.) the majority of the mixed groups included adult bulls, and the number of these bulls in the group increased twofold. Mixed groups averaged 12 (1-38) animals, and bull groups averaged $2(1-7)$. During the winter period the bison formed large aggregations around feeding places (maximum 97 animals). Also discussed is a comparison of the study population of European bison with the population living in the Bialuwieża Primeval Forest in the 19th century and with the American bison, Bison bison.

[Białowieża Nat. Park. 17-230 Białowieża, Poland].

1. Introduction

2. Study area

3. Material and methods

4. Description of the bison population in the Bialowieza Primeval Forest

5. Population dynamics

5.1. Natality

5.2. Mortality

5.3. Variations in numbers

6. Density

7. Spatial structure 
8. Group composition

8.1. Summer period

8.2. Winter period

9. Group size

9.1. Summer period

9.2. Winter period
Discussion

References.

\section{INTRODUCTION}

At the beginning of the 20th century European bison were to be found only in two geographical distan't regions, that is, the Białowiezia Primeval Forest and in the Caucasus Mountains. The fact that lowland bison persisted under natural conditions longest in the Białowieża Forest was not due to the forests exceptional natural advantages, but to the special protection extended to this species. The complete elimination from the Forest, in the 18th century, of red deer, which formed a game animal far more difficult to obtain than bison illustrates this.

According to Wroblewski (1927) there were 727 bison in the Białowieża Primeval Forest before the first World War, of which not a single animal survived that period of hostilities. The data on which the last bison died in the Białowieża Primeval Forest has been established as 1919 (S z a f e r, 1919; Wr ó ble ws k i, 1927).

European bison were brougth to the Forest again from a zoological garden in 1929, since when they have been in process of restoration. The lengthy process was very difficult during the initial phase and only reached a new level in quality after free breeding took place.

Caucasian bison have not persisted in their pure form up to the present day. Białowieża bison with an admixture of Caucasian bison blood have been differentiated in the line of Białowieża-Caucasian bison and are bred separately. The last bison of this line were taken from reserves in the Polish part of the Białowieża Forest in 1950 (K rasinski 1968), and from the Soviet part of the Forest in 1968 ( $\mathrm{K}$ or o c k in a, 1971). The whole of the Białowieża Primeval Forest is now settled solely by Białowieża bison.

There were 343 (158 males, 185 females) European bison by 31 December 1973 in Poland, living in four free-living centres (Białowieża Primeval Forest, Bieszczady Mountains, Borecka Forest and Knyszyńska Forest). Of this number $253(112,141)$ lived in the Białowieża Forest, and this was the most numerous free population of European bison in Poland. In addition to the free herd at Białowieża $23(5,18)$ animals were kept separately in enclosed reserves. 
Data in the European Bison Pedigree Book show that there were 1553 European bison in the world at the end of 1973. It is particularly interesting that of this number, 652 animals lived in free-living centre in Poland and the Soviet Union ( $\mathrm{Z}$ a b i n ski, 1976). In these countries the number of bison living under conditions of freedom exceeded the number of bison bred in reserves. The development of free-breeding shows that even under current habitat conditions this form of breeding is not only possible, but is also the most appropriate way to full restoration of this species.

The establishment of free-breeding herds has provided the means of obtaining details of many aspects of the life led by European bison in the Białowieża Primeval Forest. P u c e k (1967) emphasised the need to undertake studies on the natural history of these animals in the widest possible sense, since the lack of such studies formed a serious gap in the state of our knowledge of this species.

The purpose of this study was to ascertain population dynamics, sex and age structures, group composition and size, density and spatial structure, and different aspects of natality and mortality of the free population of bison in the Białowieża Primeval Forest. Information on these questions is not only of importance in adding to our knowledge, but also in relation to the size and food supply and definition of the extent to which bison affect forests, should it prove necessary to work out methods for rational management of European bison populations. Definition of optimum numbers, ways and extent of additional feeding or regulation of the numbers of this species are all connected with this concept.

It also seems very important to compare the natural history of European and American bison, two species of the same genus, originating from a common ancestoral stock and living for thousands of years on two continents with differing habitat conditions. Studies on restoration of American bison were begun earlier than on European bison and the degree to which the natural history and behavior of this species has been examined is greater: McHugh (1958, 1972), Fulle r (19F9, $1960,1961)$, Banfield \& Novakowski (1960), Egerton (1962), Shackleton (1968), Shult (1972) and Meagher (1973).

\section{STUDY AREA}

The Białowieża Primeval Forest is situated near the eastern frontier of Poland, and the area it covers is defined by the following coordinates: $23^{\circ} 31^{\prime}-24^{\circ} 21^{\prime}$ east longitude and $52^{\circ} 29^{\prime}-52^{\circ} 57^{\prime}$ north latitude. From its geographical aspect this region belongs to Eastern Europe and lies in the belt of European lowlands. 
The whole area of the Forest is almost completely flat, there being no important elavations, and average height above sea level is $165-170 \mathrm{~m}$.

The western part $\left(580 \mathrm{~km}^{2}\right)$ lies within Polish frontiers, and the eastern part $\left(670 \mathrm{~km}^{2}\right)$ in the Soviet Union. The total area of the Bialowieża Primeval Forest is $1250 \mathrm{~km}^{2}$. The wooded area is slightly smaller $\left(1100 \mathrm{~km}^{2}\right)$. During the last 300 years the forest area has decreased by about $45 \%$ (F a lin s k i, 1968).

The present study is concerned exclusively with the western part of the Forest and the European bison living there. The name Białowieża Primeval Forest or simply Forest has been used in this paper to define that part of it lying within Polish territory. The National Park is situated in this part, occupying the central region of the Forest over an area of 4747 ha, in which for over 50 years, that is, since 1921, no form of either forestry or hunting management has been carried out. Normal forestry management takes place in the remaining area, measuring 52,963 ha. Of this part 49,906 ha $(94.2 \%)$ is occupied by wooded land, the remaining area consisting of fields, meadows, roads, wasteland etc.

The most important component of the Białowieża Primeval Forest is formed by deciduous forest, with oak, hornbeam and lime trees, covering $26.6 \%$ of the total wooded area. Coniferous forest forms $39.0 \%$, mixed deciduous forest $20.6 \%$ and alder woods $13.8 \%$ ( $\mathrm{Puce} \mathrm{k}$ et al., 1975). In 1968 tree stands over 100 years old, fragments of ancient stands of the Forest, occupied $30 \%$ of the area, whereas before the first World War they occupied about $80 \%$ of the Forest (Wiecko, 1972).

The natural food supply of European bison is supplemented by special management of certain areas in the form of what are known as feeding glades, but the percentage formed by such areas is small in comparison with the wooded area, being only $0.5 \%$.

The Bialowieża Primeval Forest is situated in the temperate climate zone. Average precipitation is $594 \mathrm{~mm}$, average temperature in the warmest month, July, $17.6^{\circ} \mathrm{C}$, and in the coldest month, January $-4.3^{\circ} \mathrm{C}$ (data for period $1949-1964$ ). Snow cover persists on an average for 92 days, and its maximum depth for the period 1961-1971 varied from 26 to $95 \mathrm{~cm}$. The duration of the growing season, according to phytophenological criterion, lasts 185 days at Białowieża and is 30 days shorter than in the west of Poland, and 15 days shorter than in Central Poland (O ls zew s ki 1968).

Two small rivers flow through the western part of the Forest, the Narewka and Leśna, while in other smaller streams the water level is low during the summer, for instance in Eutownia brook. The greatest concentration of European bison is found in the region of the middle reach of this small river. There are na separate bodies of water in the western part of the Forest apart from marshy land within tree stands.

The animals living in the Forest exert a considerable influence on the vegetation there, and their excessive multiplication in certain periods before the first World War disturbed the homeostasis of local biocenoses. The period between World War I and II was distinguished not only by the absence of European bison as a natural component of the local fauna, but also by the relatively low number of ungulates.

After World War II the numbers of deer there began to increase. In 1968 numbers of red deer estimated by means of tracks in the snow in both parts of the Forest (West and East) exceeded 4000, and roe deer numbered almost 3000, while the number of moose was estimated as about 50, chiefly in the eastern part of the Forest (Milkowski 1969; Romanovski \& Kočanovski, 1971). 
In light of new studies, the data based on tracks greatly under-estimated the numbers of ungulates ( $\mathrm{P} \mathrm{u} \mathrm{c} \mathrm{e} \mathrm{k}$ et al., 1975).

European bison in the Białowieża Primeval Forest were formerly, and are at present, in a special position, since they are under State protection. They are, however, only one of the components of the ungulate community and therefore their role in the wooded ecosystems of the Forest must be examined from many aspects.

\section{MATERIAL AND METHODS}

Observations of European bison were carried out since the start of freebreeding, that is, since 13th September 1952. Observations from the initial period of breeding (1952-1956) consisted mostly of loose bits of information and were concerned chiefly with the places in which these animals were encountered. During the second period, from 1957-1960, particular attention was paid to the question of reproduction in the free herd and the behaviour of a large group of $19(5,14)$ bison released during this period from reserves to freedom. Systematic observations from 1961-1967 supplied data used to elucidate dynamics and dispersal of bison during this period.

Since May 1968 the introduction of "European bison observation cards" enabled observations to be made in a uniform way. Each time a group of bison or a single bison was encountered the observer completed one card. Cards were also completed when no bison were encountered in the inspection area. These negative observations were of use in analyzing dispersal of the herd, density, and biotope preferences.

Areas most frequently penetrated by the bison were divided into three observational regions (Fig. 1), which were inspected in summer during the same period by a group of workers in the Białowieża National Park (6 wardens and the author). Use was also made of observations supplied by forestry staff and other persons. Other parts of the Bialowieża Primeval Forest, in which mainly small bull groups lived, were not included in the plan of systematic observations.

From 1966-1970 2400 observations were entered on cards, over 800 of which were made in summer. These observations formed a basis for ascertaining density, spatial organization, biotope preference, and group size and composition. When working on the dynamics of numbers material from the start of free breeding up to the end of 1973 was taken into account, in order to obtain a more compleie picture.

All observations were analyzed separately for two distinctly defined and greatly differing periods. The first of these periods, termed the summer period, lasted from May to October, when the bison wandered freely through the forest. The second period, winter, covered the period from December to March. During this period the bison collect in groups in places where supplementary food is provided. April and May formed a transitional period and, depending on atmospheric conditions, were included to a greater or lesser degree to the two periods given above.

The date, time of direct observation of bison and the place in which they lived, in the form of the number of the forest sections into which the Forest is divided, were entered on the card. The average area of a section is 111 ha ( $\mathrm{Pucei}$ et al., 1975). Each section is divided into 4 parts (quarters), given capital letters $\mathrm{A}, \mathrm{B}, \mathrm{C}, \mathrm{D}$. The number and the quarter of the section were recorded, thus more accurately limiting the observation site to an area of about 28 ha. The kind of 
observation site was next defined according to the following categories: clearing and crop, meadow (cultivated or natural), cultivated fields and game area. When bison were encountered in wooded land the type of tree stand was recorded, distinguishing between: coniferous forest, mixed deciduous forest, deciduous forests and alder woods.

The number of bison was defined exactly, or approximately if it proved impossible to count them accurately.

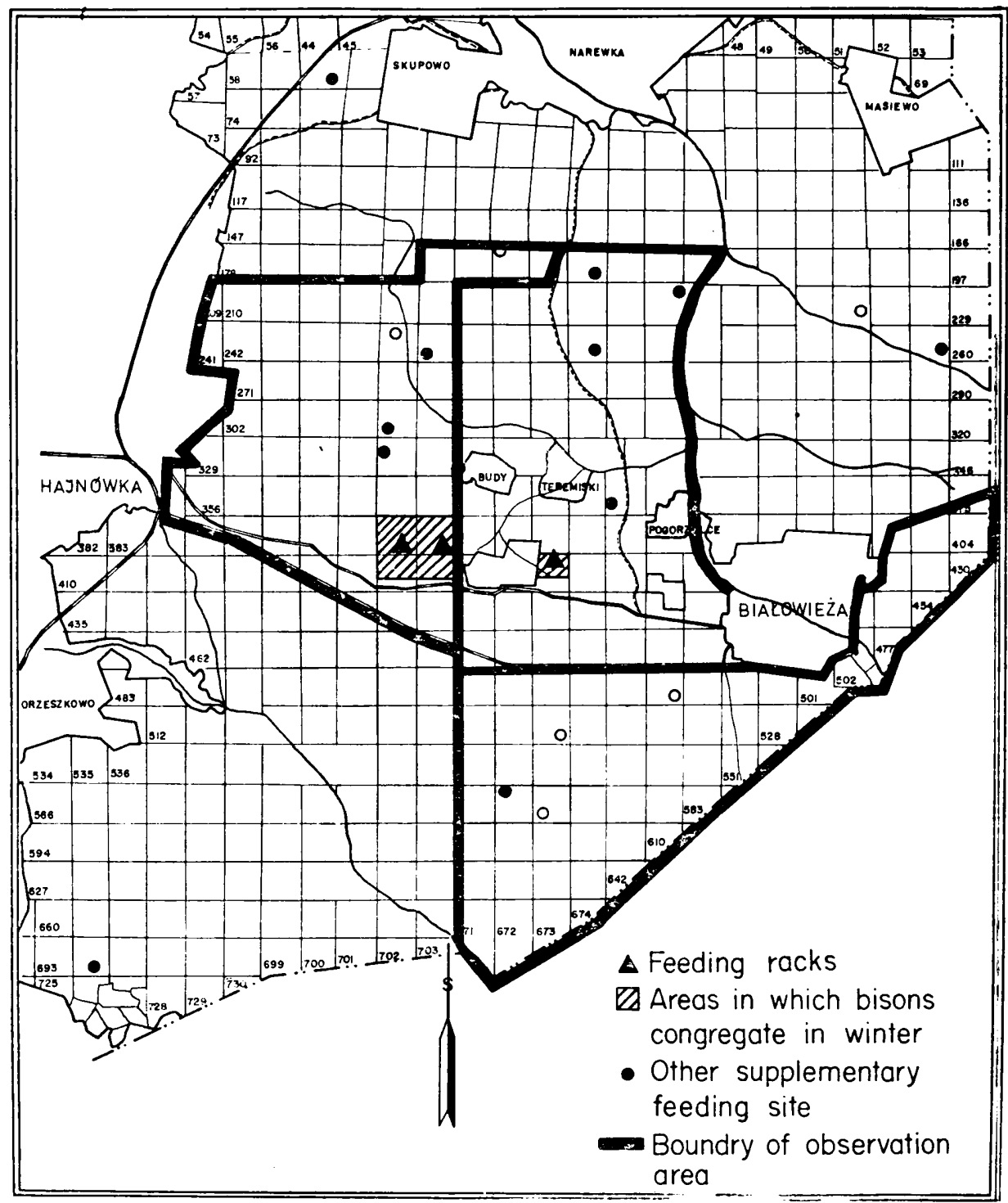

Fig. 1. Observation areas of European bison in the Bialowieża Primeval Forest from 1968-1970 during the summer period and supplementary feeding sites during the winter period. 
The term herd used in this paper applies to all bison occurring in the Bialowieża Primeval Forest.

Bison occurred in groups of two types. Mixed groups included bison of both sexes. The following classes were distinguished: adult cow bison over 4 years old, juveniles from 2-3 years old, calves and, periodically, adult bulls (over 4 years old). It is easy to distinguish between sexes in adult bison on account of clearly marked sexual dimorphism. The basic criterion for allocating bison to one of the age classes within a mixed group was the size of the individuals, while size and shape of horns was an auxiliary factor. Calves up to one year old have straight horns, whereas in young animal about 2 years old the horns begin to incline medially. In 3-year old animals they are well formed and similar in shape to those in adult bison, but smaller. The horns of aduit buils are large and massive, slightly bent towards the centre. Cow bison have thinner horns, strongly bent medially. Individuals of both sexes up to the age of 1 year were allocated to the calf class. When the groups broke up in the early spring of the following year this group of calves was allocated to the $2-3$ year old animal class. In the calf class the approximate time of birth can be defised on the basis of the state of advance or completion of the juvenile moult.

The second type of groups consisted of bull groups (including single bulls) regardless of age. An attempt was made to estimate the age of bison in ciasses within the bull group as follows: young bulls ( $4-5$ years old), adults $(6-10$ years) and old bulls over 10 years old.

In studies on American bison populations, $\mathrm{McHugh}(1958,1972)$ distinguished groups of bulls and cows, Fuller (1960) and $\mathrm{Shacklet}$ ( $\mathrm{n}$ (1968) used the terms "mixed groups" and "bull groups", Shult (1972) used the terms: groups of cows with calves, bull groups and solitary bulls. She joined solitary bulls to bull groups, analyzing, e.g. their size. Similar procedure has been used in the present study, including single individuals in analysis of mixed groups and bull groups.

Observations made during the winter period were of a different character, since it was then possible to cover the whole population of bison by observations at different supplementary feeding sites. The two chief such sites were inspected daily, and the remainder at least once a month.

Definition of the numbers of bison, with particular attention to young animals, was made by the method of estimating total numbers. Stocktaking of bison was carried out in January or February depending on atmospheric conditions, when all the bison had congregated on the different supplementary feeding sites. Losses were recorded currently over the whole year.

\section{DESCRIPTION OF THE BISON POPULATION IN THE BIAEOWIEŻA PRIMEVAL FOREST}

Age and sex structure of the bison population were considered in the following classes: adult bulls and cows (4 years old and older), juveniles from $2-3$ years old and calves up to one year old. The division into the above classes is based on easy identification in the open. During the period in which detailed examination was made of the structure of bison population, that is from 1968-1970, the percentage formed by the different classes in the whole population altered very 
little (Fig. 2). If this question is traced in the three following years $(1971-1973)$ then it can be seen that similar sex and age structure is maintained. This leads to the conclusion that the European bison population in the Białowieża Primeval Forest is beginning to stabilize.

A large number of factors have contributed to formation of this particular structure of the bison population in the Forest, one of which was introductions. During the whole period of free breeding of these animals, $38(14,24)$ bison were released in the Forest. The sex ratio of introduced bison was thus approximately $1: 2$. From 1952-1962 the free herd was formed of young animals $1-3$ years old, while the two

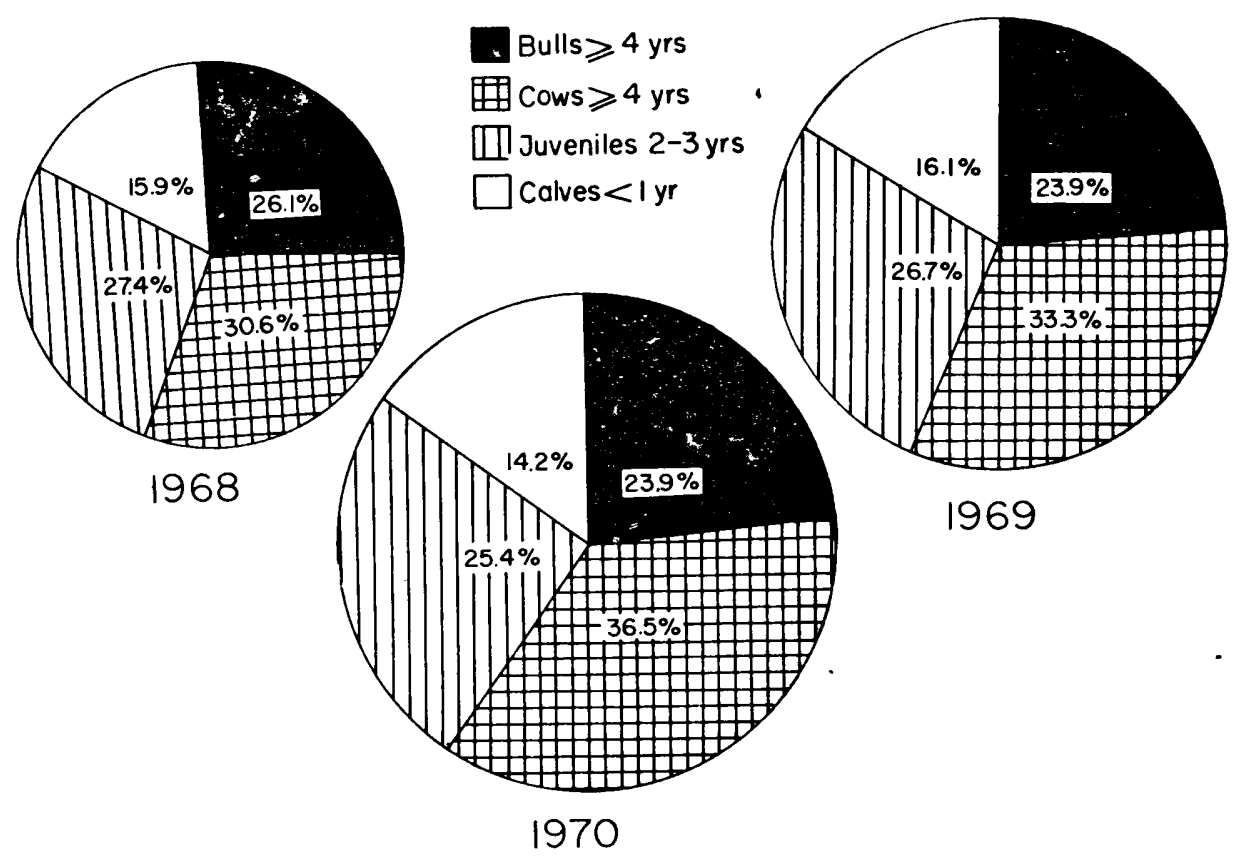

Fig. 2. Structure of bison population in 1968, 1969, 1970.

adult cows released together with the juveniles were the leaders of their groups. In the following period (up to 1966) a group of $10(3,7)$ bison from 8-17 years old were released from the enclosed reserves. The story of the formation of this population has been described, previously (K r a s inski, 1967). Since 1967 all intervention in the bison herd ceased with no new animals released except for one male in 1972 (Table 1).

In 1970 the number of bison in the free herd which originated from reserves formed only $9 \%$ of the entire herd, and in $1973-5.5 \%$. During 
the next few years, on account of natural mortality, the Białowieża population will consist solely of individuals born in freedom. Sex ratio and birth is the next factor which exerts an important influence on population structure. During the whole period of free breeding (1952-1973) a total of 316 calves were born, 161 of which were bull calves, 155 heifers. This ration does not significantly differ from the ratio of $1: 1$ $(P<0.05)$, but in different years considerable deviation was observed from this ratio (Table 1 ).

Table 1

Numbers of the free herd of European bison in the Białowieża Primeval Forest from $1952-1973$.

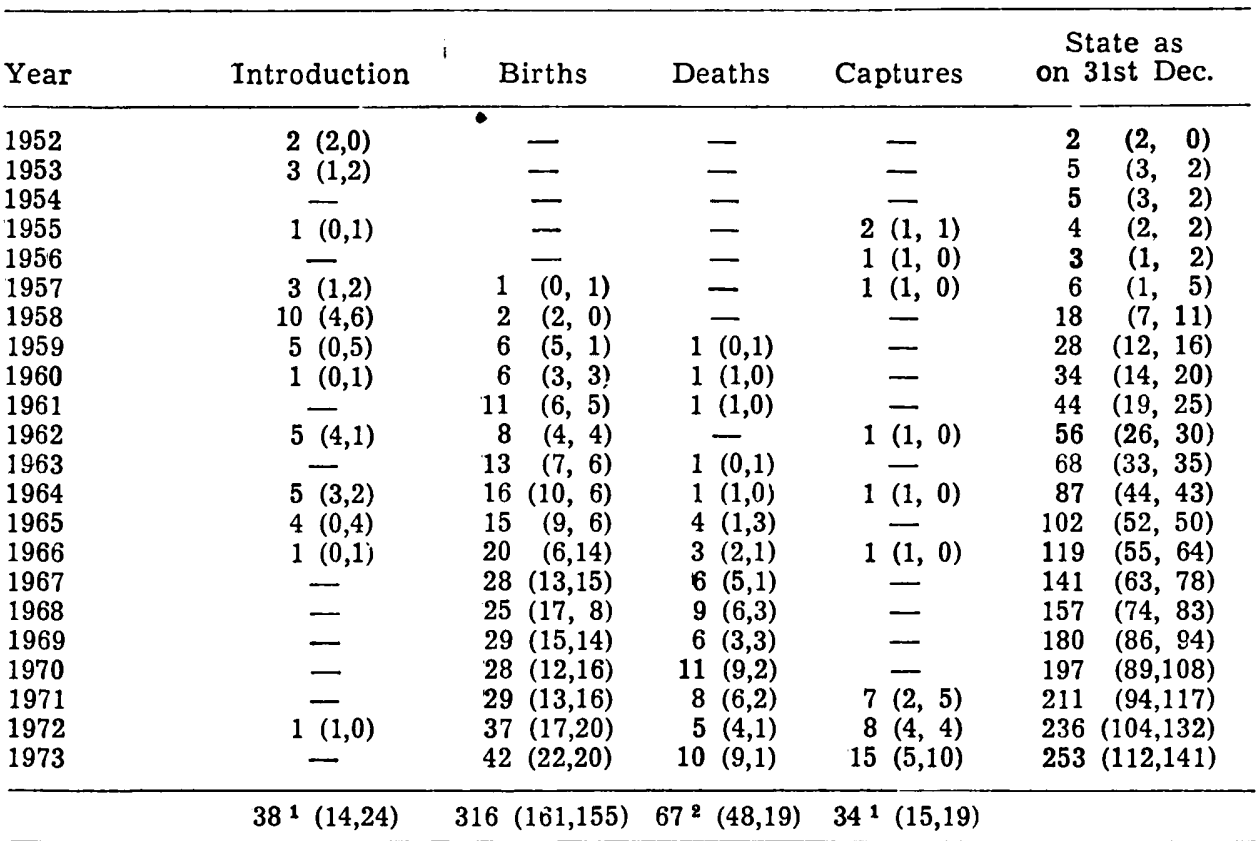

1 Three animals caught and later released were not taken into consideration.

2 Jointly with bison eliminated from breeding.

Utilization of the herd was initiated in 1971 with the capture of $7(2,5)$ young bison, which were next transferred to the Borecka Forest $(3.3 \%$ of the whole herd). In $19728(4,4)$ bison were caught, which made $3.4 \%$ of the whole population, and in $197315(5,10)$ bison $5.9 \%$. A total of $30(11,19)$ bison from the juvenile class were caught in these three years (Table 1).

An important factor affecting population structure and dynamics was mortality, which is discussed in the section on population dynamics.

$\mathrm{As}_{\mathrm{i}}$ the result of the effect of the above factors, a structure was 
created in the bison population which is illustrated by the age pyramid drawn up for the final study year (1973), and which was due to the greater longevity of the females than male bison.

During the first years of breeding introduction exerted a decisive influence on population structure (1952-1959) and during the subsequent period the basic factor was natural reproduction. In later years utilization, begun in 1971 , will play an increasingly greater role.

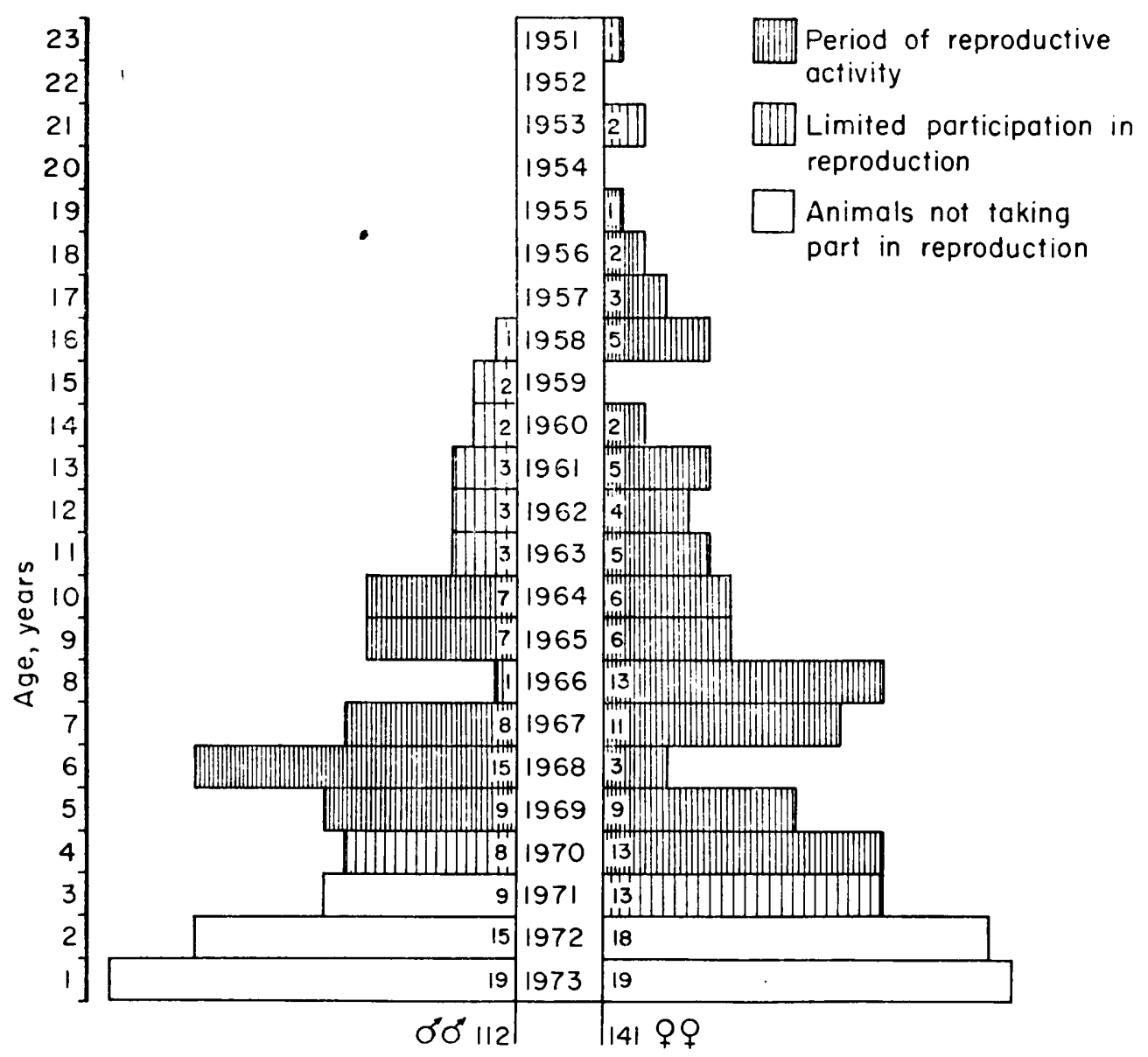

Fig. 3. Age pyramid of bison population in the Bialowieża Primeval Forest according to head of bison on 31st December 1973.

Since the start of free breeding the bison have been supplied with supplementary food in winter the Białowieża Primeval Forest, in the shape of hay provided ad libitum. Although other wild ungulates are also given supplementary food (red deer, wild boar, roe deer) it is only 
in the case of European bison that supplementary feeding so significantly affects behaviour, social structure, density and even reproduction. The average length of the supplementary feeding period in the case of bison from 1960-1971 was 163 days ( \pm 36 days). The length of this period depended on the time at which the bison approach the feeding places and also the time at which they leave them. Hay is stored in stacks and is potentially accessible to the bison as early as July. Up to 1968 when hay was stored in enclosed places, supplementary feeding was started as soon as the bison approached the established feeding places (Fig. 1). The length of the supplementary feeding period also depends on weather conditions, primarily on the length of time for which the snow cover persists (Fig. 4). The longest period for which bison made use of hay was 181 days during the long and severe winter of $1969 / 70$. During this winter the continuous snow cover also persisted

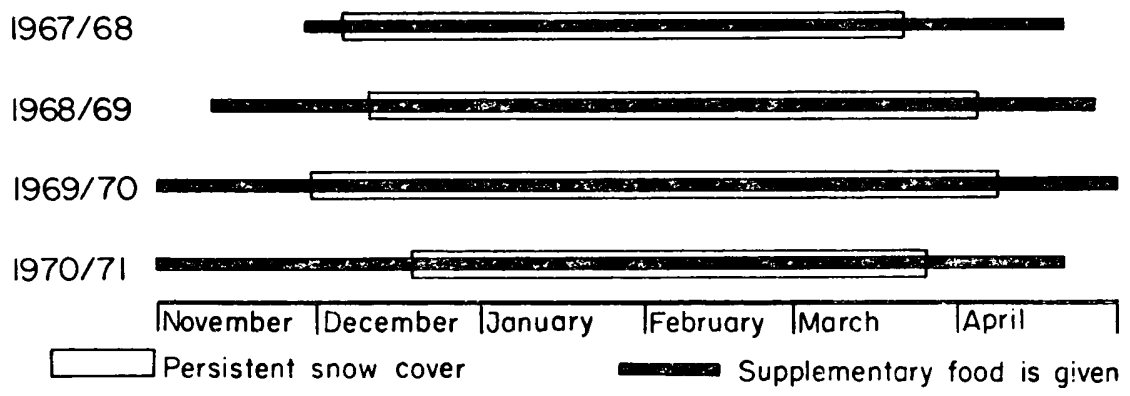

Fig. 4. Effect of time for which snow cover lies and length of time for which bison make use of winter supplementary feeding in the Białowieża Primeval Forest from $1967-1971$.

longest - for 131 days. Maximum depth of snow cover was $95 \mathrm{~cm}$, that is, more than twice greater than in previous winter periods. Bison made use of supplementary food for the shortest time, i.e. only 145 days, during the winter period 1967/68, when the time for which continuous snow cover persisted was 108 days, the maximum depth of snow being only $36 \mathrm{~cm}$.

The greatest consumption of hay, within limits of $70-80 \%$, takes place in December, January, February and March. During this period hay forms almost $100 \%$ of the animals' diet. Decrease in the amount of hay consumed can be observed in November and April, when the bisior fail to make regular use of the supplementary food. During a winter with little snow some of the bulls did not approach the feeding places for a long time, for instance in 1964 it was not until 8 March, 
after a heavy snowfall, that 3 bulls approached a feeding place for the first time. Food obtained from under the snow now plays a minimum role, such activity being observed chiefly in bulls emerging from the forest into fields and cultivated meadows during the early part of winter (Photo 1, Plate I).

\section{POPULATION DYNAMICS}

The indices describing dynamics of numbers were calculated on the basis of data for the period 1960-1973. The initial period of breeding was omitted as insufficiently representative, on account of small numbers and unnatural structure of the herd.

In analyzing the reproduction potential of the free herd of bison the indexes of reproduction elaborated for bison living in reserves were taken as a basis. The average age of a female bison when calving for

Table 2

Coefficient of births $(\%)$ of calves-expresed as ratio of number of calves born to population size $(n)$ during period $1960-1973$.

\begin{tabular}{lccc}
\hline Year & $\mathrm{n}$ & No. of calves born & Coeff. of births, \% \\
\hline 1960 & 28 & 6 & 21.4 \\
1961 & 34 & 11 & 32.3 \\
1962 & 44 & 8 & 18.2 \\
1963 & 56 & 13 & 23.2 \\
1 C64 & 68 & 16 & 23.5 \\
1965 & 87 & 15 & 17.2 \\
1966 & 102 & 20 & 19.6 \\
1967 & 119 & 28 & 23.5 \\
1968 & 141 & 25 & 17.7 \\
1969 & 157 & 29 & 18.5 \\
1970 & 180 & 28 & 15.5 \\
1971 & 197 & 29 & 14.7 \\
1972 & 211 & 37 & 17.5 \\
1973 & 236 & 42 & 17.8 \\
Total & & & \\
$1960-1973$ & & 207 & 18.5 \\
\hline
\end{tabular}

the first time was its fourth calendar year of life, the average being 47.8 months. The reproduction potential of a female bison from the time of reaching sexual maturity remains on an unchanging level $(72 \%-85 \%)$ until the time reproductive function ceases at the age of 20 years ( $\mathrm{Krasinski} \& \mathrm{Raczynski} 1967$ ). In making caculations the possibility of twin pregnancy was not taken into consideration as these are extremely rare cases in the genus Bison.

\subsection{Natality}

Reproduction is the element of population dynamics in bison by means of which increase takes place. Reproduction is presented as the 
expression of the participation of the whole or of certain groups of the population in reproduction. The coefficient of births defined as the ratio of the number of calves born to total population size (according to the state at the beginning of the year) calculated for $1960-1973$, was on an average $18.5 \%$. The maximum coefficient was recorded in $1961-$ $32.3 \%$, and the lowest in $1971-14.7 \%$. As from 1968 the value of the coefficient is maintained on a level below the average calculated for the whole period and varied from $14.7 \%$ to $18.5 \%$ (Table 2). During this period a decrease in the rate of population growth was recorded. Since the basis for calculating the coefficient of births is formed by the whole population, it would be more useful to define the reproduction potential on the basis of analysis of the coefficient of fecundity, which defines the number of progeny in relation to the number of females in the period of reproduction. The fecundity coefficient from

Table 3

Coefficient of fecundity $(\%)$ - expresed as a ratio of the number of calves born number of fema'es capable of reproduction $(r)$ during period 1967-1973

\begin{tabular}{lccc}
\hline Year & $\mathrm{n}$ & No. of calves born & Coeff. of fecundity, \% \\
\hline $1958-66^{*}$ & 138 & 97 & $53-89(70.3)$ \\
1967 & 38 & 28 & 73.6 \\
1968 & 42 & 25 & 59.5 \\
1969 & 46 & 29 & 63.0 \\
1970 & 59 & 28 & 47.4 \\
1971 & 69 & 29 & 52.0 \\
1972 & 71 & 37 & 53.8 \\
1973 & 78 & 42 & 54.1 \\
Total & & 218 & \\
$1967-1973$ & & & \\
\hline
\end{tabular}

* After Krasiński \& Raczyński, 1967.

1958-1966 is from $53 \%-89 \%$, average $70.3 \%$ (K rasinski \& R ac z ynski, 1967). In the subsequent period from 1967-1973 it fell from an average level of $54.1 \%$, with variations from $73.6 \%$ in 1967 , to a minimal value in $1971-42.0 \%$ (Table 3 ). Thus not much more than $56 \%$ of females capable of reproduction produce young each year.

\subsection{Mortality}

Mortality depends not only on the physiological length of the individual's life, but also on the effect of different habitat, population and biocenotic factor which cause the ecological mortality of the population to be a variable value. 
The coefficient of mortality among bison in the free herd - from 1959-1973 calculated as the ratio of number of deaths to size of the whole population (according to the state at the end of the year) was $3 \%$. In all $62(43,19)$ bison died in the free herd. The coefficient changed in different years from the minimal value of $0 \%$ found in 1962 to a maximal value of $5.7 \%$ recorded in 1968 (Table 4). The greater mortality among males, $69.4 \%$, than among females must also be emphasized. This relation differs significantly from the ratio $1: 1$ $(P<0.01)$.

Losses in the bison population were traced in five age classes, while percentage of mortality was calculated in intervals of one year of life.

Table 4

Coefficient of mortality $(\%)$; expresed as a ratio of the number of dead bison to population size $(n)$ during period $1959-1973$.

\begin{tabular}{lccc}
\hline Year & $\mathrm{n}$ & No. of dead bison & Coeff. of mortality, $\%$ \\
\hline 1959 & 28 & 1 & 3.6 \\
1960 & 34 & 1 & 2.9 \\
1961 & 44 & 1 & 2.3 \\
1962 & 56 & 0 & 0 \\
1963 & 68 & 1 & 1.5 \\
1964 & 87 & 1 & 1.1 \\
1965 & 102 & 4 & 3.9 \\
1966 & 119 & 3 & 2.5 \\
1967 & 141 & 6 & 4.2 \\
1968 & 157 & 9 & 5.7 \\
1969 & 180 & 6 & 3.3 \\
1970 & 197 & 11 & 5.6 \\
1971 & 211 & 7 & 3.3 \\
1972 & 236 & 3 & 1.3 \\
1973 & 253 & & 3.2 \\
Total & & 62 & 3.0 \\
$1959-1973$ & & & \\
\hline
\end{tabular}

1 Five $(5,0)$ eliminated from breeding were not taken into consideration.

Maximum mortality was recorded in class I (calves up to 1 year) $22.6 \%$. In the next classes this percentage decreased, and the lowest value of $2.1 \%$ and $2.6 \%$ was found in the two classes of oldest bison (Fig. 5). This type of mortality is characteristic of the majority of natural populations, for instance in the natural population of American bison in Wood Buffalo National Park in Canada the number of progeny is reduced by almost half over the course of a year (up to the following spring) (F u ll e r, 1961).

In analyzing mortality in different months a relatively balanced distribution of deaths was found over the course of a whole year. Maximum values were found in August, $11.3 \%$, in September 14.4\% (max- 
imum value) and in March $11.3 \%$ (Table 5). The increased percentage of deaths during the rutting period is connected with the increased aggressiveness of the bulls, while increased mortality in March, towards

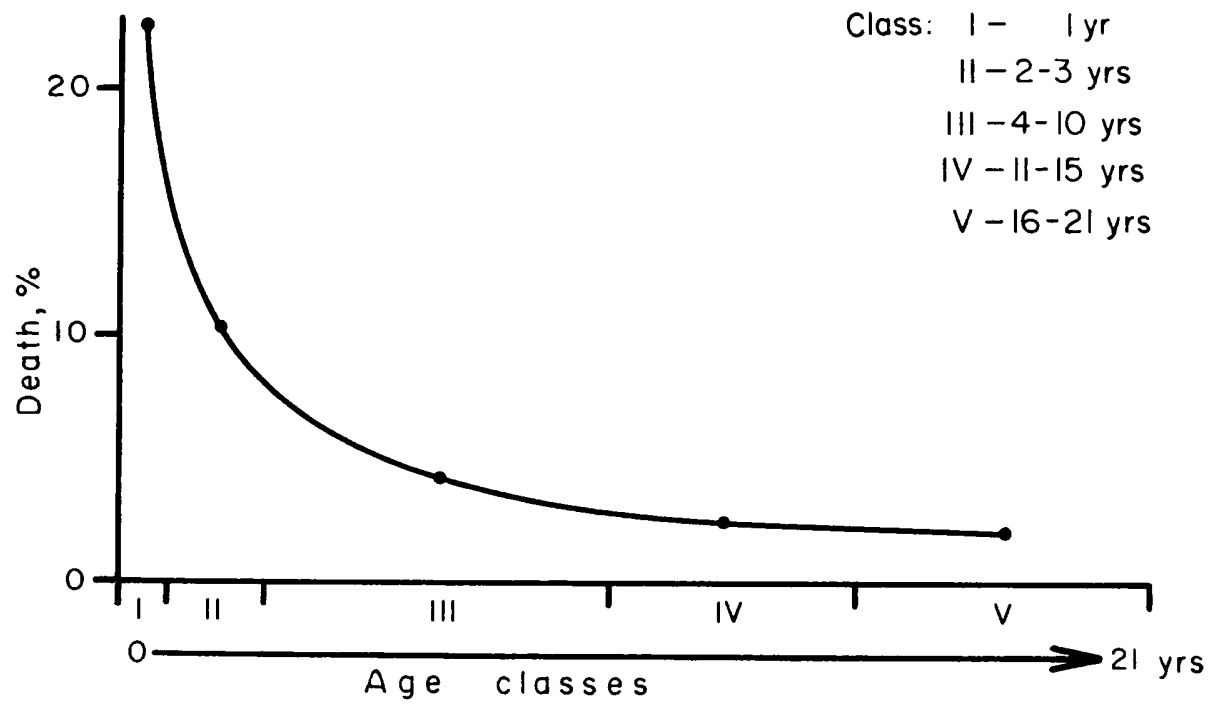

Fig. 5. Mortality among bison depending on age during period 1959-1973.

Table 5

Mortality among bison depending on the season from $1959-1973$.

\begin{tabular}{lcr}
\hline Month & No. of dead bison & \multicolumn{1}{c}{$\%$} \\
\hline January & 5 & 8.1 \\
February & 4 & 6.4 \\
March & 7 & 11.3 \\
April & 5 & 8.1 \\
May & 4 & 6.4 \\
June & 2 & 3.2 \\
July & 5 & 8.1 \\
August & 7 & 11.3 \\
September & 9 & 14.5 \\
October & 4 & 6.4 \\
November & 5 & 8.1 \\
December & 5 & 8.1 \\
Total & 62 & 1000 \\
\hline
\end{tabular}

the end of the winter period, is connected with deaths of the weaker animals.

Among causes of death mechanical injuries occupy first place, being respor over $30 \%$ of all deaths, and over $20 \%$ of these are caused 
by the bison themselves. Contagious diseases were not observed in the free herd ${ }^{1}$.

\subsection{Dynamics of Numbers}

In analyzing dynamics of numbers the first period (1952-1957) was omitted when the population was in the phase of initial growth and its numbers $(2-6$ animals) were below the value essential for initiating true growth. Further introductions and the start of reproduction in

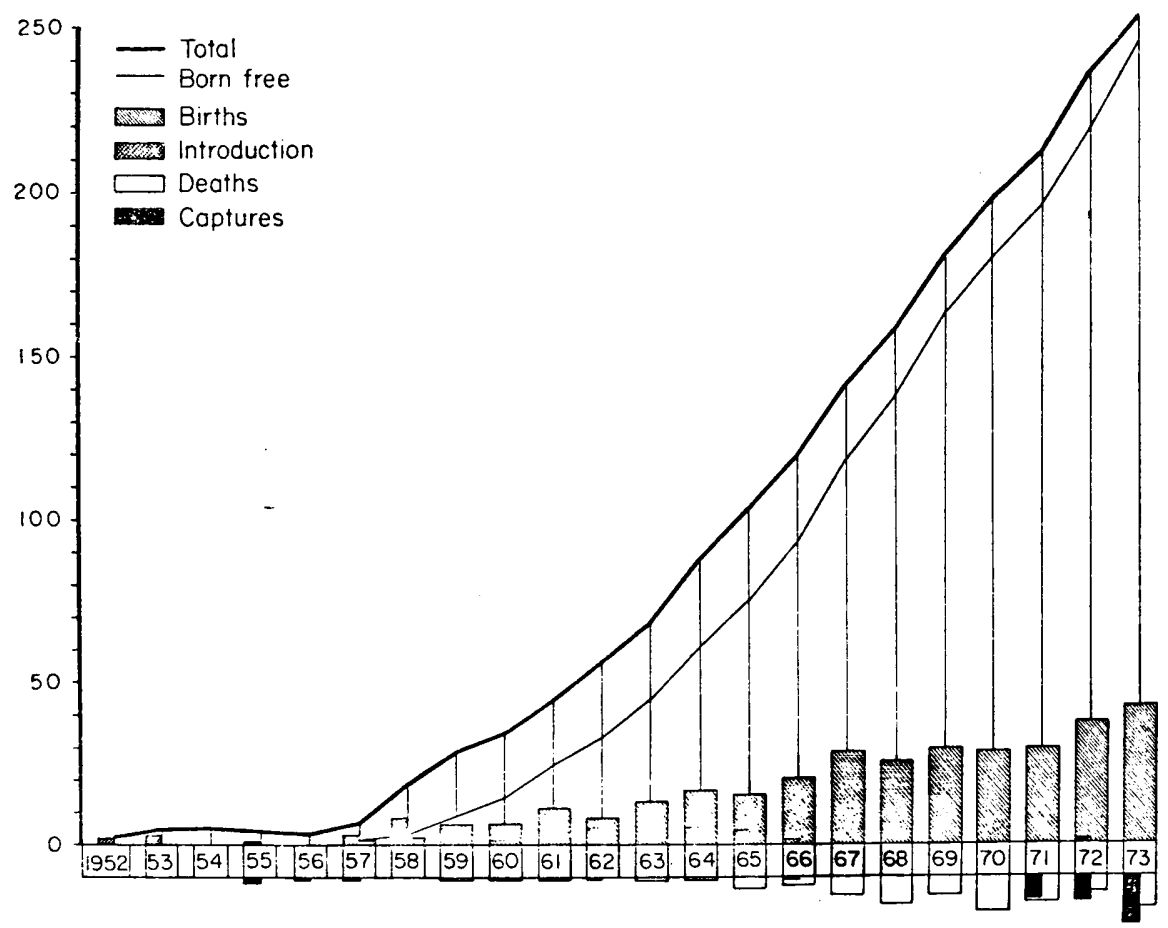

Fig. 6. Dynamics of numbers of bison in the Białowieża Primeval Forest from 1952-1973.

1958 and 1959 enabled the population to enter the growth phase. In subsequent years the curve is exponential in character and increase in numbers takes place chiefly through natural increase (Fig. 6). In the case of large mammals this phase may thus occupy a long period, for

1 Detailed analysis of causes of death will be published elsewhere. 
instance in reindeer (Rangifer tarandus) it is 40 years ( $\mathrm{c} \mathrm{h}$ ef fer, 1951, cited from $\mathrm{Schwerdtfeger}$ 1968). The bison population increased despite the fact that the reproduction indices are far below their potential capacity. This is due to the low mortality rate of the whole population. The growth phase may by fellowed by the population establishing itself on a given level, or may be followed by a period of decrease. At present the bison population in the Bialowieża Primeval Forest (western and eastern parts jointly) has reached approximately half the numbers of the natural population in the 19th century (Fig 7). Without human intervention increase could continue, although certain observations indicate that the population is tending to consoli-

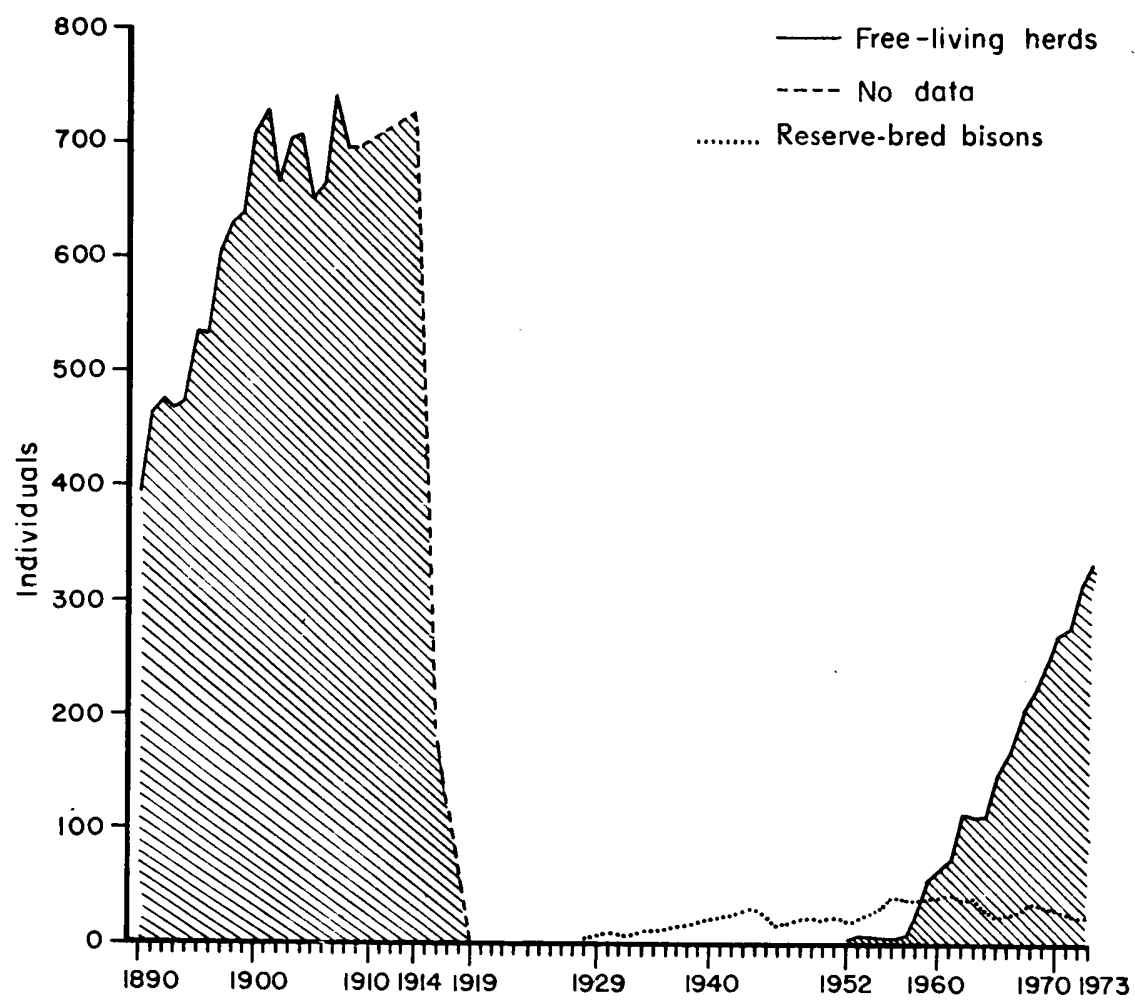

Fig. 7. Dynamics of numbers of bison in the Bialowieża Primeval Forest from 1890-1973 (data after Karcov, 1903; Wróblewski, 1927; Krąsiński, 1968; K o r o čki na, 1969; European Bison Pedigree Book).

date its numbers and to pass from the growth phase to the phase of relative equilibrium via slower growth. In this connection it is primarily through decrease in fecundity and increase in the average of the population (Table 3, Fig. 3). 


\section{DENSITY}

In order to calculate total density the area of the whole western part of the Forest was taken into consideration, that is, 57,710 ha, calculating

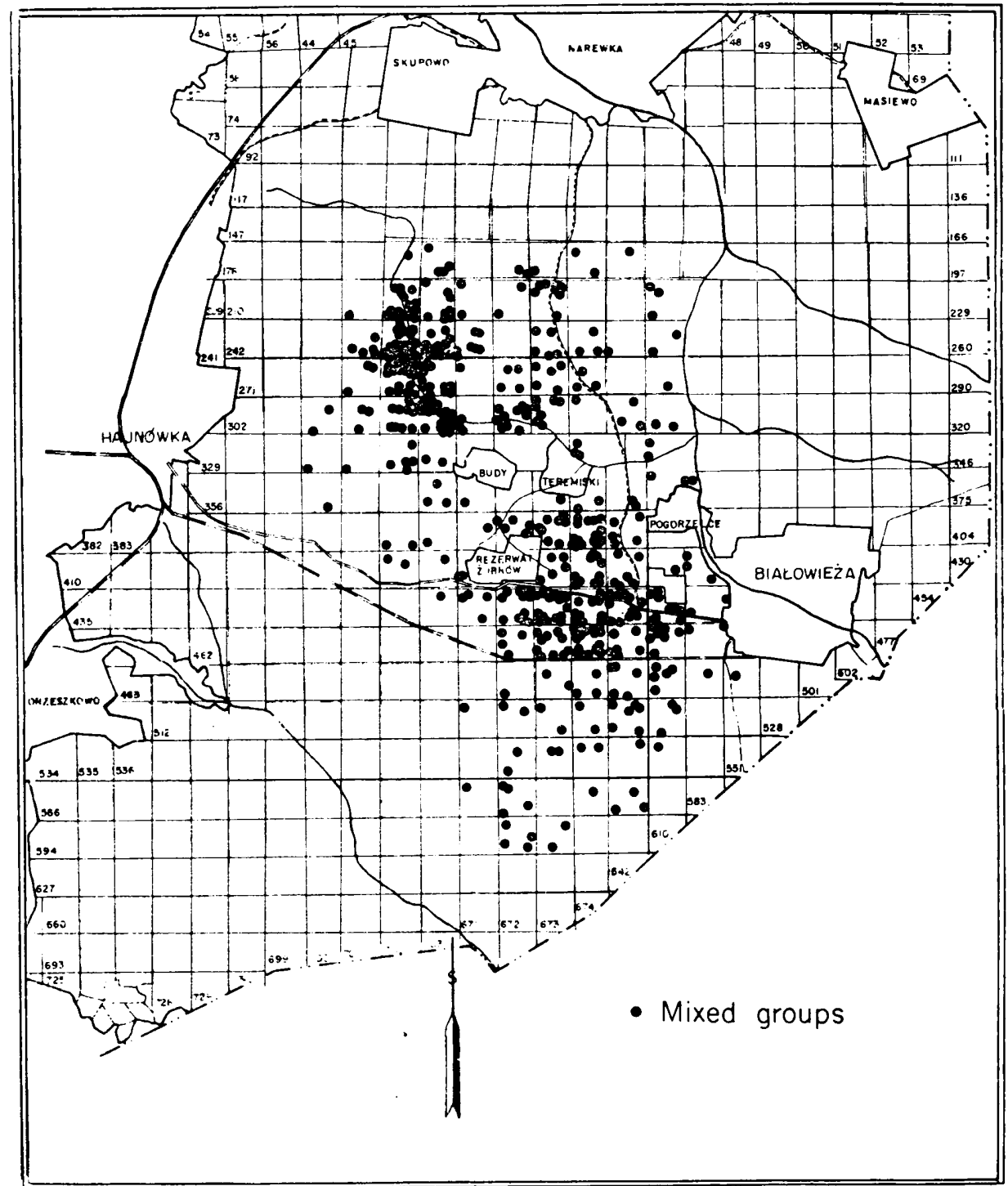

Fig. 8. Distribution of mixed groups from 1968-1970 (May-November).

the index for the whole bison population. When calculating true density, however, only the area in which mixed groups and the majority of bulls were present was taken into consideration. In calculation of this 
density those groups of bulls (about $20 \%$ of the whole population) which lived distant from the remaining groups, i.e. on the northern and southern boundaries of the Forest, were omitted. These groups, each numbering from 2-6 bulls, appeared in these boundary areas in 1963 and 1964 and remained distant from the main groups up to the end of these observations (1973).

During the initial period of free breeding growth of the bison population was accompanied by increase in their living area, thus density did not increase. This process was observed up to 1966. In that year the population reached a total 102 animals ( $\mathrm{K} \mathrm{r}$ a s ińs ki, 1967). From 1967-1970 the population did not continue to spread, despite the fact that at the end of 1970 the herd had almost, doubled to 197 animals. Density of the bison therefore increased with population growth. Average density of bison over the area of the whole Forest (total density) in 1966 was 1.7 animals/1000 ha, but in 1970 , this had risen to 3.4 animals $/ 1000$ ha. The area intensively occupied by mixed groups and bull groups was 13,200 ha and was situated in the central part of the Forest. True density was 12 bison per 1000 ha in 1970 , and in this region it is possible to find areas of increased concentration, particularly near the middle reaches of the River Eutownia (Fig. 8).

During the winter density abruptly rises as a result of different mixed groups congregating in places where supplementary food is laid out in winter. In the supplementary feeding areas all the females, juveniles and calves congregate within an area of about 200 ha, and some of the bulls also live with these groups. Density is thus very high, in this case about 200 animals/1000 ha.

In the bull groups increase in concentration is far smaller, since from, 60 to $90 \%$ of adult bulls do not use these two chief feeding places but wander over a great part of the Forest in winter.

During the winter period density increased together with population size.

\section{SPATIAL STRUCTURE}

The spatial structure of mixed groups differs from that of bull meval Forest is group-aggregational in character. This means that the way in which the bison live consists of formations of groups of different size, the distribution of these groups not being even but exhibiting certain aggregations.

The spatial structure of mixed groups wiffers from that of bull groups and single bulls. Distribution of mixed groups is more aggregational, this applying both to places in which groups concertrate and to the total area occupied by mixed groups (Fig. 8). 
Bull groups are distributed more unevenly, and exhibit particularly greater dispersion over the whole area of the Forest (Fig. 9). The presence of bull groups was found in areas where mixed groups are

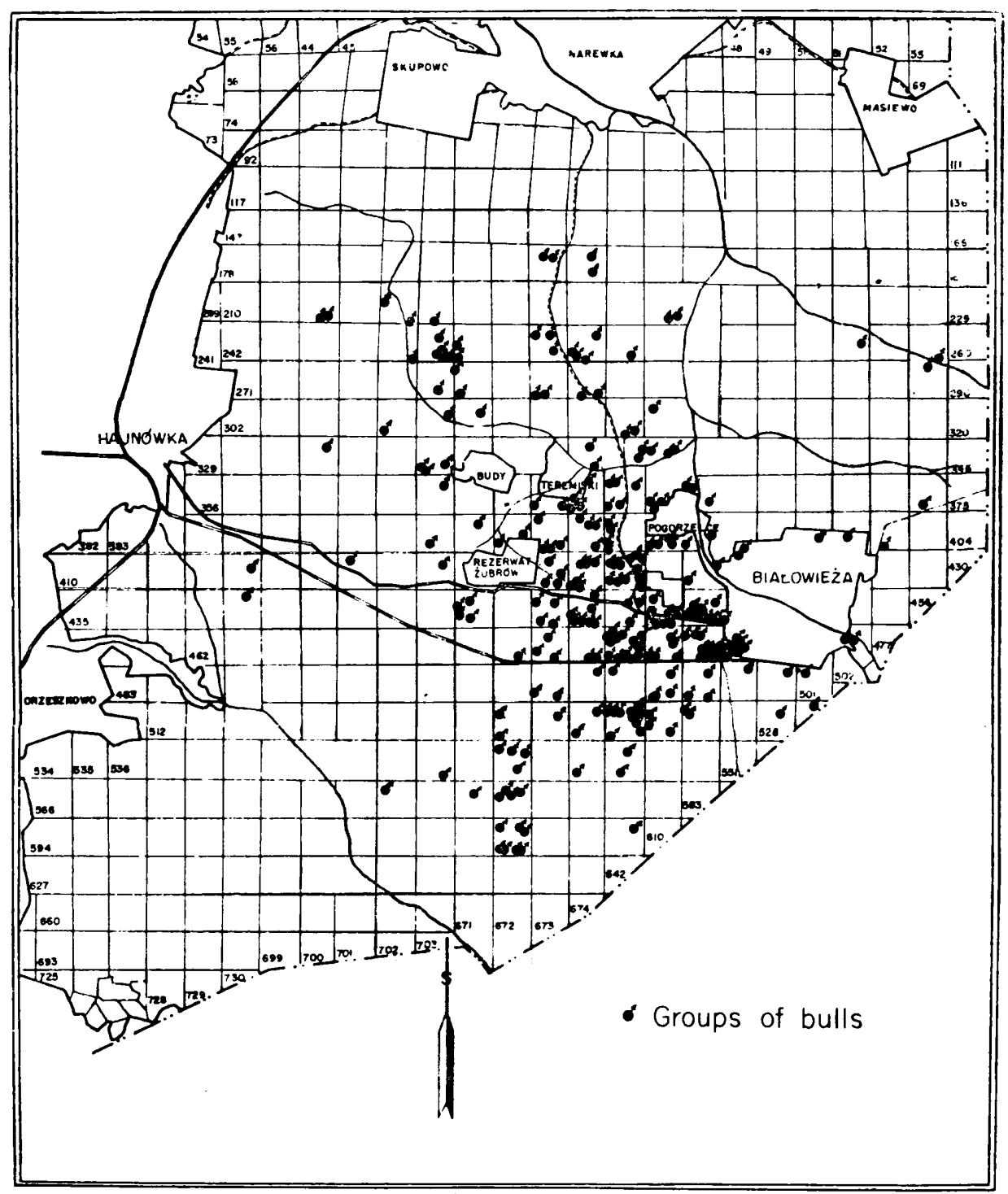

Fig. 9. Distribution of bull groups from 1968-1970 (May-November).

nut encountered, e.g. the north-west regions or north-east and southwest regions of the Forest.

Distinct seasonal changes in spatial structure can be observed between 
the summer and winter periods. During the winter the distribution of mixed groups and bull groups can be defined as similar to islands, usually limited to supplementary feeding places. Congregation and combining of mixed groups during winter into larger communities (up to the present two) is most probably not only due to the existence of these supplementary feeding sites but also to the formation of this behaviour pattern in bison. For instance the first attempts, made from 1967-1968, and also subsequent attempts, at splitting the bison congregation during winter in two mixed communities, into smaller units by laying out hay in 20 additional places, were unsuccessful.

Formation by bulls of larger communities for the winter period is far less strongly expressed. For instance in 1968-1971 bulls formed $5-9$ separate groups characterized by low stability.

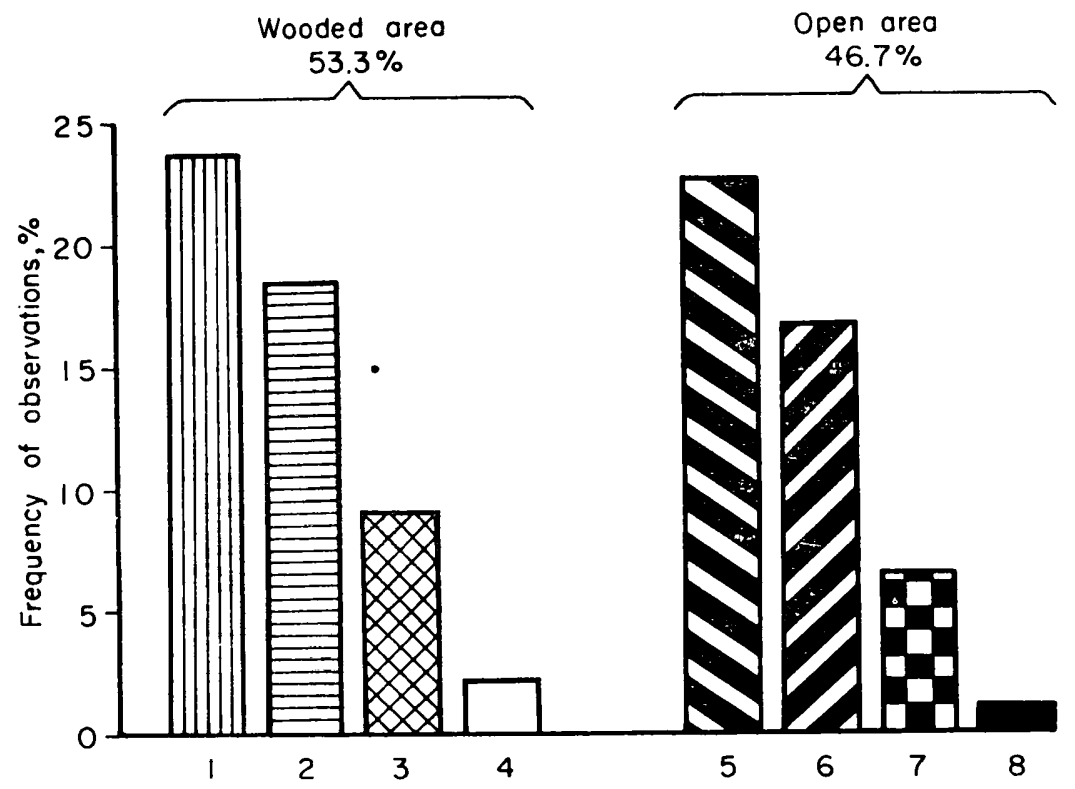

Fig. 10. Frequency of bison (mixed groups and bull groups) in different biotopes from 1968-1970. 1. coniferous forests; 2. mixed deciduous forests; 3. alder woods; 4. deciduous forests; 5 . clearings; 6 . meadows; 7 . cultivated fields; 8 . other.

Biotope conditions exerted a definite influence on the distribution of mixed groups and bull groups in summer. However the observational methods used in this study do not permit exact definition of the biotope preferences of European bison. Even so a large number of observations $(n=831)$ obtained in an area of mosaic biotope types permits a general definition of habitats preferred by these animals.

In a comparison of the freguency with which bison are encountered 
in wooded and open areas (clearings, meadows, cultivated fields etc.) $53.3 \%$ of the encounters took place in wooded areas. Of these wooded biotopes, coniferous forests are the least penetrated $(2.1 \%$ of encounters) and next alderwoods (9\% of encounters). Bison were most of ten encountered in mixed deciduous forest $(23.7 \%)$ and deciduous forest $(18.5 \%)$ (Fig. 10).

Bison often feed in open areas such as forest glades, cultivated fields. Clearings and cultivated areas are allocated to this category regardless of the biotope type in which they occur, since in such cases this type plays more of a secondary role and preference applies to open space covered by young vegetation. Bison were encountered in clearings and crops in all months of the summer period $\left(22.6^{0} \%\right.$ of all encounters). The next most visited were meadows $(16.7 \%)$ and cultivated fields $(6.4 \%)$. The remaining $1.0 \%$ consisted of encounters impossible to allocate to any one of the categories mentioned (Fig. 10).

Bison wery frequently feed on the meadows situated high above the River Eutownia (Photo 2) and in the forest glade called Worobiowa. They make less use of unmown meadows of this type. Of the uncultivated meadows, wet and overgrown by sedge, whether situated inside the forest or on the banks of the Narewka, Hwoźna and Leśna rivers, the bison now make no use whatsoever.

Differences in intensity of stay by mixed groups and bull groups were found only in cultivated fields, where bulls were encountered in $83.7 \%$ of all cases.

On account of the great variety of forest types over a relatively small area it was difficult to establish seasonal differences.

\section{GROUP COMPOSITION}

\subsection{Summer Period}

Mixed groups include bison of both sexes of different ages in their composition (Photo 3). The composition of the group is not constant but is subject to seasonal changes. This can be seen when analyzing the percentage composition of mixed groups during the three-year study period (1968-1970) over the course of seven months from May to November (Table 6). During the rutting season, that is, in August, September and even October, the number of mixed groups including adult bulls (4 years old and older) in their composition increases. In August they formed $79.8 \%$ of all mixed groups, and this percentage rose to $86.8 \%$ in September. It decreased in October but was still high, i.e. $74.7 \%$. By November, however, there was marked reduction in the number of groups in which adult bulls were present to the level 
Table 6

Composition of mixed groups from 1968-1970 (May - November).

Avg. - average value; O. R. - observed range.

\begin{tabular}{|c|c|c|c|c|c|c|c|c|c|c|c|c|c|}
\hline \multirow[b]{2}{*}{ Nunth } & \multirow[b]{2}{*}{$\mathrm{n}$} & \multicolumn{3}{|c|}{ Males } & \multicolumn{3}{|c|}{ Females } & \multicolumn{3}{|c|}{$2-3$ yrs old } & \multicolumn{3}{|c|}{ Calves $<1$ yr } \\
\hline & & Avg. & $\%$ & O.R. & Avg. & $0 \%$ & O.R. & Avg. & $0 / 0$ & O.R. & Avg. & $\%$ & O.R. \\
\hline May & 66 & 0.7 & 7.1 & $1-4$ & 4.4 & 46.2 & $1-18$ & 4.1 & 42.9 & $1-12$ & 0.4 & 3.8 & $1-7$ \\
\hline June & 50 & 0.6 & 7.2 & $1-2$ & 3.9 & 45.8 & $1-13$ & 3.2 & 37.4 & $1-11$ & 0.8 & 9.6 & $1-6$ \\
\hline July & 62 & 0.6 & 6.7 & $1-2$ & 4.0 & 41.3 & $1-11$ & 3.5 & 37.0 & $1-12$ & 1.4 & 15.0 & $1-6$ \\
\hline August & 104 & 1.5 & 13.6 & $1-8$ & 4.2 & 38.4 & $1-13$ & 3.6 & 32.9 & $1-14$ & 1.6 & 15.1 & $1-7$ \\
\hline September & 61 & 1.5 & 13.7 & $1-4$ & 4.3 & 39.3 & $1-9$ & 3.4 & 30.9 & $1-10$ & 1.7 & 16.1 & $1-6$ \\
\hline October & 83 & 1.1 & 12.2 & $1-4$ & 3.6 & 38.8 & $1-14$ & 3.1 & 33.2 & $1-20$ & 1.5 & 15.8 & $1-7$ \\
\hline November & 31 & 0.8 & 11.1 & $1-3$ & 3.5 & 48.7 & $1-8$ & 2.1 & 28.3 & $1-6$ & 0.9 & 11.9 & $1-3$ \\
\hline
\end{tabular}


observed during the pre-rutting period, when these groups formed $54.8 \%$ of all mixed groups (Fig. 11).

The participation of adult bulls in mixed groups also increased during the rutting period, the largest number of bulls in mixed group being observed in August and September, when they formed respectively $13.6 \%$ and $13.7 \%$ of all components of the groups. Maximum participation of bulls was found in August $1968-16.1 \%$ (Table 6).

During the calving season, in May, June and July the participation of bulls in mixed groups was almost half of what it had been during the rutting period. Bulls formed on an average $7.1 \%$ (May) and $7.2 \%$ (June) of the remaining components of a mixed group. The lowest

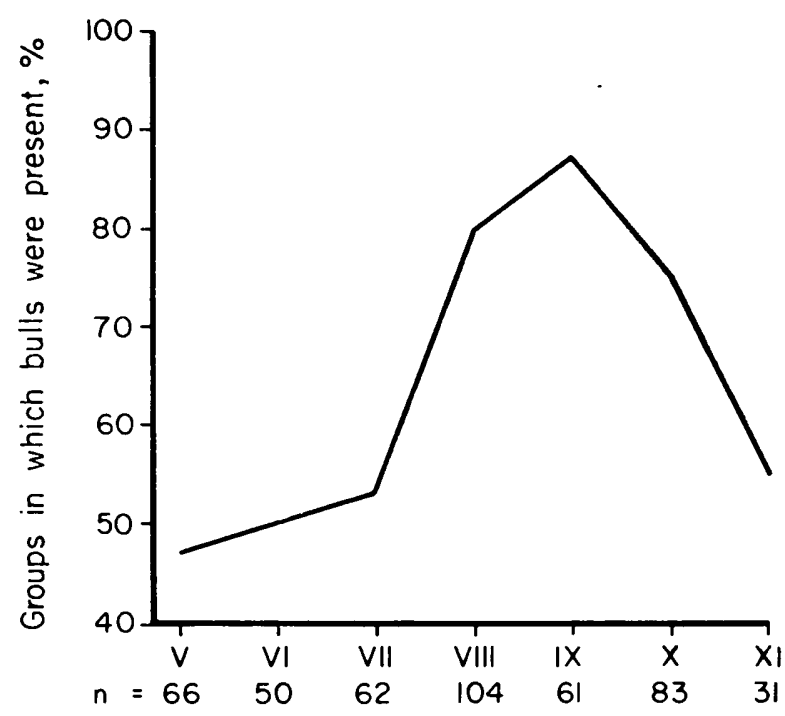

Fig. 11. Presence of bulls (4 years old and older) in mixed groups trom 1969-1970 (May-November).

percentage of bulls in mixed groups was observed in July, when the average figure was $6.7 \%$ (Table 6 ).

The second component of which the percentage in mixed groups varies in different months of the year is formed by calves. It is obvious that mixed groups should increase by the number of newborn calves in group, but rising in June to $9.6 \%$ and subsequently remaining on a similar level during the period from August to October, forming 15\% of the group (Fig. 12). 
In the class of females 4 years old and older and juveniles from 2-3 years old no distinct seasonal fluctuations are observed. Adult cows form $38.4 \%-48.7 \%$ of an average mixed group, while the participation of juveniles varies within limits of $28.3 \%-42.9 \%$ (Table 6).

When the structure of mixed groups was analyzed over the threeyear period it was found that the number of bulls in an average mixed group was 0.6 animals during the calving period, rising to 1.5 animals during the rutting season. The number of cows varied from 3.5 to 4.4 animals, juveniles from 2.1 to 4.1 animals and calves from $0.4-1.7$ animals (Table 6).

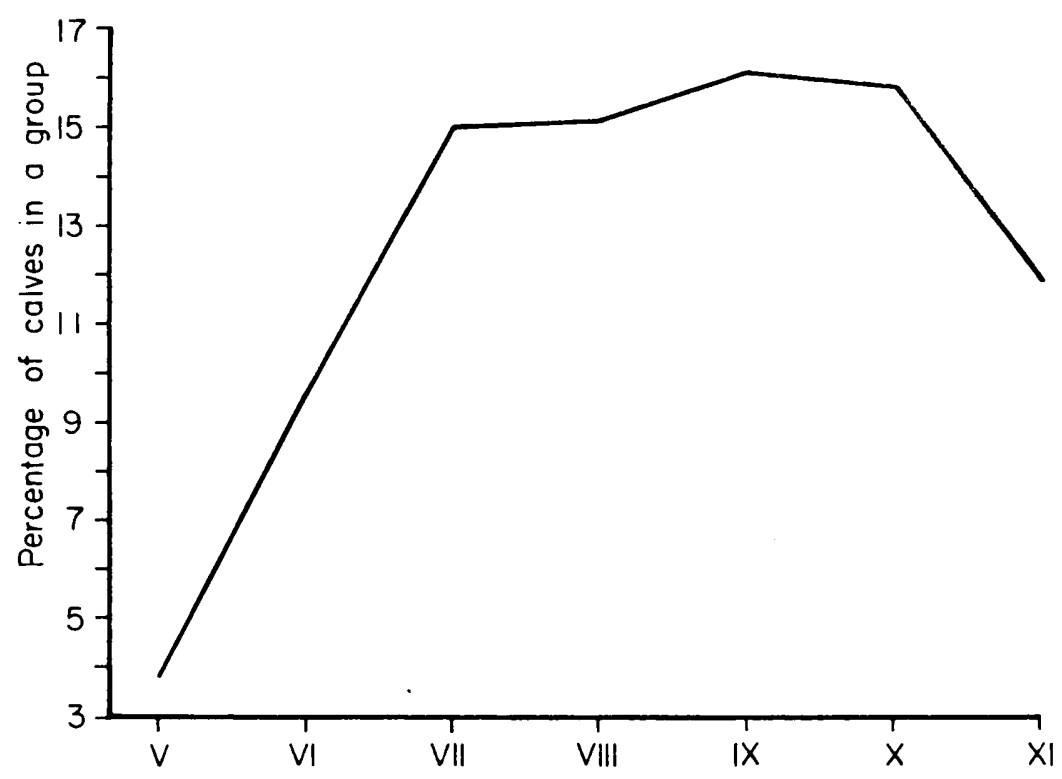

Fig. 12. Presence of calves in mixed groups from 1968-1970 (May-November).

The greatest number of cows in one mixed group was found in May 1970 , when they numbered 18 , juveniles in October $1970-20$ and maximum number of calves -7 animals, frequently observed in different months.

In the majority of cases $(60.6 \%)$ only one adult bull is encountered in groups, two individuals were found in $27 \%$, three in $8.2 \%$, and four in $3.6 \%$. A total of 6 and 8 bulls was found in a group twice only (Fig. 13). During the rutting period the percentage of groups containing more than one bull increases, and in September groups containing a single bull formed only $43.4 \%$ of the groups (Fig. 14). 


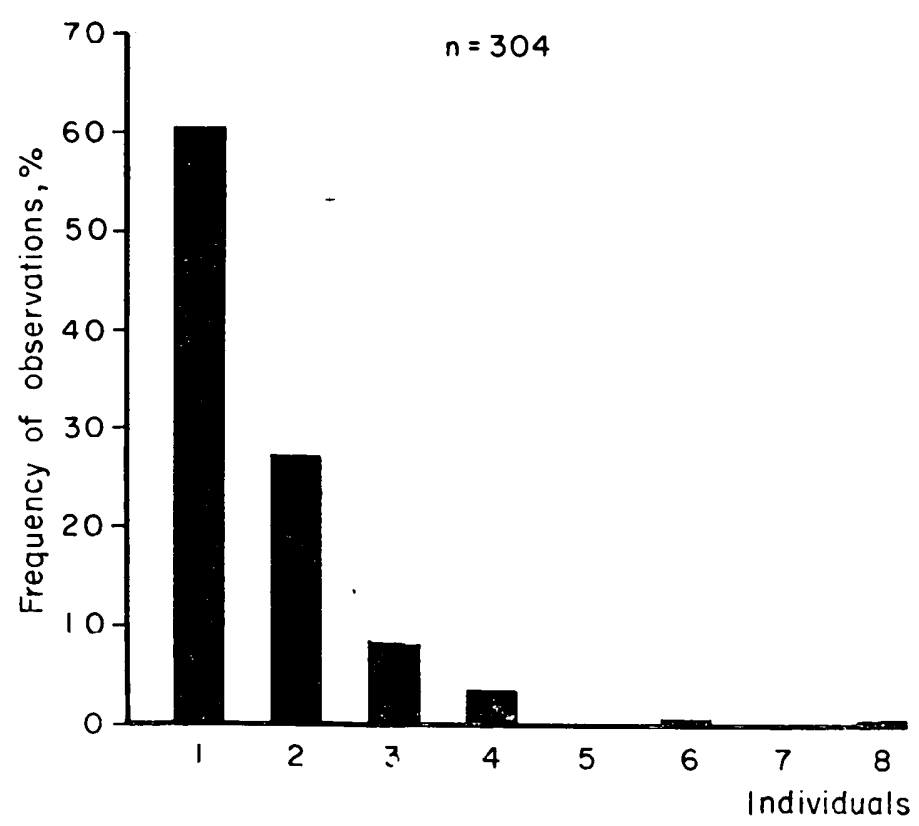

Fig. 13. Number of adult bulls in mixed groups from 1968-1970 (May-November).

Groups consisting of juveniles only were not, however, encountered, and in larger groups in which juveniles predominated there were usually several adult females which led the group.

During the rutting period typical groups, of medium or large size and full composition, predominate. The presence of calves contributes to the greater stability of these groups during this period, since the calves

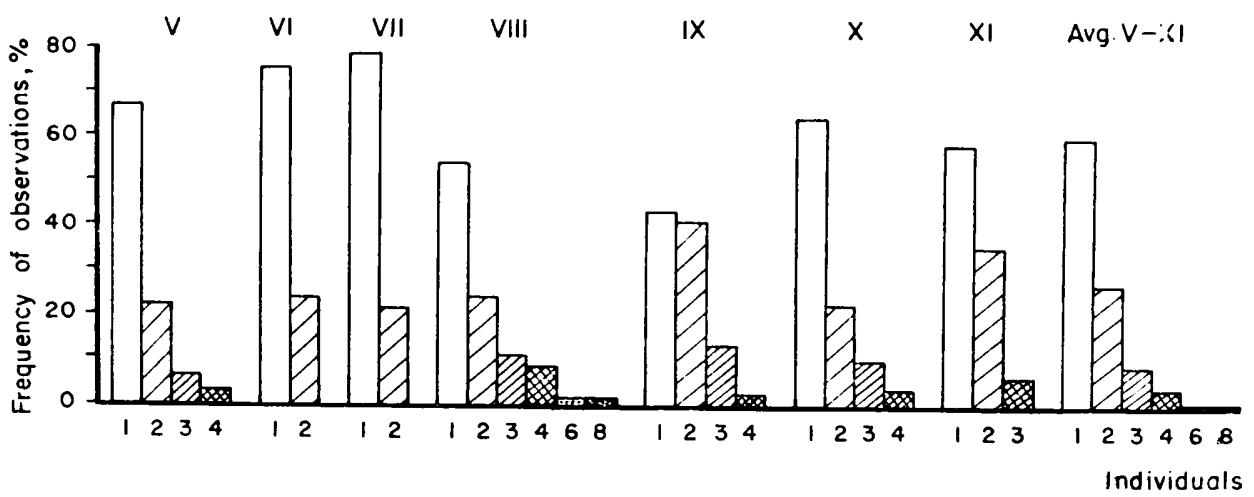

Fig. 14. Number of adult bulls in mixed groups from 1968-1970 depending on the season. 
keep together, causing the groups to be more compact, and in addition when two groups combine the calves by keeping together make it difficult for the groups to split up again.

Bull groups most often consist of young individuals $4-6$ years old, year. Such groups are also encountered during the rutting season which shows that not all adult bulls join mixed groups during this period. On the other hand mixed groups which include adult bulls were encountered at all seasons of the year.

Bull groups most often consist of young individuals $4-6$ years old, 3-year old individuals being less often included in their composition. Two-year old bulls were never encountered in them. Young bulls usually combine in groups consisting of $2-7$ animals, while adult and old bulls most often lead a solitary life or, although this is rarely observed, in pairs.

\subsection{Winter Period}

During the winter period bison congregate in places where there is a constant supply of supplementary food, and they then form large aggregations as the result of a large number of groups uniting. This is connected with food laid out in established places.

The composition of such communities during the winter was exactly determined in February 1970. In the first community of bison (forest section 390 and 391 ) it was chiefly cows which had congregated, forming $45.9 \%$ of the group, juveniles $-31.1 \%$ and calves $18.9 \%$, while the number of bulls was small - 4.1\%. A small group of bison living at that time in forest section 306 did not join the first aggregation, possibly on account of the deep snow $(95 \mathrm{~cm})$. Calves formed a considerable percentage $(25.7 \%)$ of this group and also juveniles $-34.3 \%$, whereas cows formed only $31.4 \%$.

In the third large aggregation (forest section 422 ) the high percentage of bulls, not typical of mixed aggregations - 19.1\%, is remarkable, while cows formed $35.7 \%$, juveniles $-30.9 \%$ and calves $14.3 \%$. The story of the formation of this group is interesting. When the feeding rack was put up in forest section 422 (in 1958) bulls only congregated there during the winter period. In 1963 they were joined there by the first cows, including the cow "Pocieszna" released from the reserve. This cow and its calves (distinguished by the lighter colour of the ends of the horns) came to the feeding place every year. This is also evidence of the influence of family links on the composition of winter aggregations. In subsecuent years the percentage of cows and juveniles increased in this group and the largest and strongest bulls were then observed 
to move to other winter feeding places. Some of the bulls, however, remained and were thus responsible for the non-typical structure of this aggregation.

The tendency for adult bulls to remain separate from mixed groups was thus observed at the start of free breeding and was maintained in later years. During the winter stocktaking made in February 1968-1970 it was found that from $55.5 \%$ to $89.4 \%$ of the adult bulls lived outside the mixed aggregations (Table 7).

\section{Table 7}

Aggregation of bulls from 1968-1971 (winter period).

Time at which stock- Adult bulls living out- Number of individuals Number of taking was carried out side mixed aggregations in groups groups

\begin{tabular}{lccll}
\hline & $\mathrm{n}$ & $\%$ & & \\
February 1968 & 20 & $\mathbf{5 5 . 5}$ & $1-8$ & $\mathbf{5}$ \\
February 1969 & 34 & 82.9 & $1-15$ & 8 \\
February 1970 & 26 & 60.5 & $1-7$ & 9 \\
February 1971 & $\mathbf{4 2}$ & 89.4 & $1-8$ & $\mathbf{9}$ \\
\hline
\end{tabular}

\section{GROUP SIZE}

\subsection{Summer Period}

Analysis of the size of groups of bison was made for a period of 8 years $(1963-1970)$ on the basis of 1272 observations of mixed groups and 523 observations of bull groups (Table 8, 9). The period up to 1962 was omitted as being insufficiently representative on account of the low population numbers, while data from 1968, 1969 and 1970 were analyzed in greater detail.

When calculating the average size of the groups, cases in which herd size was approximately determined were also taken into consideration. Although the observer was not then exactly able to ascertain the numbers in the group, he determined a certain order of size. This applied almost exclusively to mixed groups numbering over 20 animals. If these data had been omitted it would have reduced calculated average group size. The densely wooded area and activity of the bison made it difficult to carry out an exact count of bison in such cases.

Average size of mixed groups for the whole period analyzed (1963-1970) was 11.9 animals. In the case of mixed groups dispersion of the sample was high (SD - 7.0). Despite the fact that over the course of 8 years the population increased by 3.7 fold no connection was observed between variations in group size and increase in population numbers. The lowest average value during the period referred to was 
recorded in $1968-9.9$, and highest in 1967-13.8 animals (Table 8).

The size of mixed groups from 1963-1970 varied within limits of 1-40 animals. Considerable stability of maximum numbers was found on a level of about 40 animals. The most numerous groups consisted of 38 individuals (exactly counted) and was recorded several times, for the first time in 1965.

When the size of mixed groups in different months from May to

Table 8

Size of mixed group from 1963-1970 (May - November).

O.R. - observed range; Avg. - average; SD - standard deviation.

\begin{tabular}{|c|c|c|c|c|c|c|c|c|c|c|c|c|}
\hline Months & $\mathrm{n}$ & O.R. & Avg. & $\mathrm{SD}$ & $\mathrm{n}$ & O.R. & Avg. & SD & $\mathrm{n}$ & O.R. & Avg. & $\mathrm{SD}$ \\
\hline & \multicolumn{4}{|c|}{1963} & \multicolumn{4}{|c|}{1964} & \multicolumn{4}{|c|}{1965} \\
\hline May & 14 & $3-26$ & 12.7 & \pm 4.9 & 9 & $2-25$ & 11.4 & \pm 6.6 & 41 & $2-32$ & 13.3 & \pm 8.8 \\
\hline June & 8 & $6-20$ & 13.2 & \pm 5.1 & 14 & $3-20$ & 9.8 & \pm 4.6 & 30 & $2-27$ & 8.5 & \pm 5.4 \\
\hline July & 11 & $9-20$ & 15.8 & \pm 4.4 & 15 & $6-20$ & 10.0 & \pm 5.2 & 22 & $4-22$ & 10.7 & \pm 5.3 \\
\hline August & 9 & $8-20$ & 12.1 & \pm 3.7 & 10 & $4-25$ & 12.2 & \pm 8.2 & 46 & $2-27$ & 13.8 & \pm 6.9 \\
\hline September & 16 & $5-15$ & 10.7 & \pm 4.2 & 9 & $5-15$ & 8.8 & \pm 3.6 & 47 & $3-38$ & 16.4 & \pm 6.8 \\
\hline October & 16 & $3-15$ & 7.7 & \pm 3.4 & 9 & $3-11$ & 7.5 & \pm 3.1 & 31 & $3-20$ & 15.1 & \pm 4.7 \\
\hline November & - & - & - & - & - & - & - & - & - & - & - & - \\
\hline \multirow[t]{2}{*}{ Total } & 74 & $3-26$ & 11.7 & \pm 5.3 & 66 & $2-25$ & 10.0 & \pm 5.4 & 217 & $2-38$ & 13.4 & \pm 6.9 \\
\hline & \multicolumn{4}{|c|}{1966} & \multicolumn{4}{|c|}{1967} & \multicolumn{4}{|c|}{1968} \\
\hline May & 29 & $4-20$ & 9.5 & \pm 4.5 & 48 & $2-24$ & 13.8 & \pm 6.0 & 28 & $1-30$ & 10.5 & \pm 7.2 \\
\hline June & 30 & $2-30$ & 13.2 & \pm 6.9 & 29 & $5-26$ & 14.5 & \pm 5.0 & $\begin{array}{l}20 \\
28\end{array}$ & $2-23$ & 7.9 & \pm 5.6 \\
\hline July & 21 & $5-20$ & 12.7 & \pm 4.6 & 33 & $4-30$ & 16.4 & \pm 6.6 & 21 & $1-16$ & 8.4 & \pm 4.2 \\
\hline August & 32 & $3-25$ & 13.2 & \pm 6.4 & 22 & $6-32$ & 14.8 & \pm 8.6 & 37 & $3-38$ & 12.9 & \pm 8.9 \\
\hline September & 26 & $2-30$ & 14.2 & \pm 8.1 & 21 & $3-27$ & 12.2 & \pm 6.6 & 25 & $1-30$ & 13.2 & \pm 3.6 \\
\hline Ostober & 35 & $3-16$ & 7.9 & \pm 3.7 & 34 & $2-34$ & 13.5 & \pm 7.4 & 40 & $1-33$ & 8.3 & \pm 6.8 \\
\hline November & - & - & - & - & 33 & $1-23$ & 11.2 & \pm 6.8 & 18 & $2-17$ & 6.6 & \pm 3.4 \\
\hline \multirow[t]{2}{*}{ Total } & 173 & $2-30$ & 11.3 & \pm 6.5 & 220 & $1-34$ & 13.8 & \pm 6.8 & 197 & $1-38$ & 9.9 & \pm 6.9 \\
\hline & \multicolumn{4}{|c|}{1969} & \multicolumn{4}{|c|}{1970} & \multicolumn{4}{|c|}{$1963-1970$} \\
\hline May & 38 & $1-40$ & 11.4 & \pm 9.0 & 14 & $3-30$ & 14.9 & \pm 10.1 & 221 & $1-40$ & 12.1 & \pm 7.5 \\
\hline June & 14 & $6-35$ & 12.4 & \pm 7.4 & 14 & $1-30$ & 11.7 & \pm 9.3 & 167 & $1-35$ & 11.2 & \pm 6.5 \\
\hline July & 31 & $2-27$ & 12.3 & \pm 8.1 & 27 & $2-25$ & 12.9 & \pm 7.1 & 181 & $1-30$ & 126 & \pm 6.5 \\
\hline August & 36 & $3-40$ & 9.0 & \pm 7.1 & 43 & $2-29$ & 12.9 & \pm 6.8 & 235 & $2-40$ & 12.7 & \pm 6.9 \\
\hline September & 20 & $2-19$ & 8.8 & \pm 5.6 & 23 & $3-25$ & 11.4 & \pm 5.4 & 187 & $1-38$ & 12.9 & \pm 6.9 \\
\hline October & 24 & $1-24$ & 8.7 & \pm 6.2 & 24 & $4-40$ & 14.2 & \pm 10.7 & 213 & $1-40$ & 10.6 & \pm 7.1 \\
\hline November & 10 & $2-22$ & 13.3 & \pm 6.2 & 7 & $3-12$ & 5.3 & \pm 2.7 & 68 & $1-23$ & 9.7 & \pm 6.2 \\
\hline Total & 173 & $1-40$ & 10.4 & \pm 7.6 & 152 & $1--40$ & 12.6 & \pm 8.0 & 1272 & $1-40$ & 11.9 & \pm 7.0 \\
\hline
\end{tabular}

November for the period 1963-1970 is compared it can be seen that average sizes of groups in spring (May, June), do not differ significantly from each other $(P>0.05)$, like the situation in autumn, that is, in October and November $(P>0.05)$. The greatest average group sizes for the whole of the study period were recorded during the rutting season, that is, in August and September (12.7-12.9). No significant differences $(P>0.05)$ were found between the average values of groups of bison 


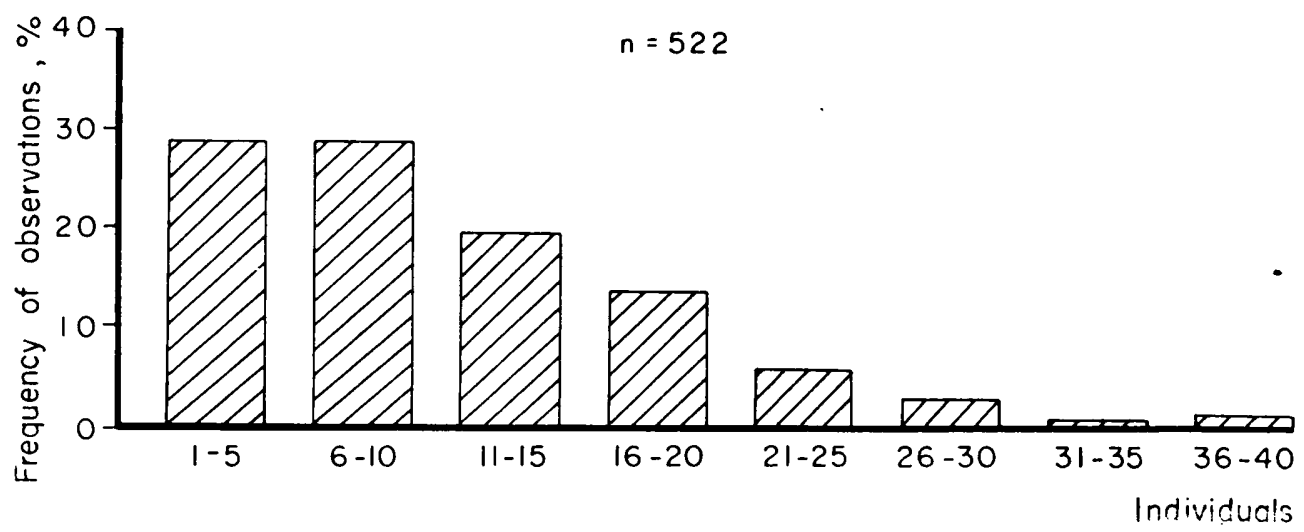

Fig. 15. Average size of mixed groups from 1968-1970 (May-November).

during these months, but they are significantly higher than in June $(0.02<P<0.05)$ and in October and November $(P<0.002)$. The lack of any significant difference in the average size of groups during the rutting period in comparison with May $(P>0.05)$ can be explained by mixed groups not having formed after the long winter period, as they did for instance in May $1970(\bar{x}=14.9)$. Analysis of average values from different years also confirms that the largest groups (except for July 1973 and October 1969) are encountered during the rutting months (August and September). The greatest average group size during the whole period occurred in September 1965 - 16.4 (Table 8).

In order better to illustrate numbers of mixed groups they have been arranged in 8 size groups. Maximum frequency was found for groups up to 10 animals, whereas their frequency decreases as group size increases (Fig. 15).

Bull groups are less numerous than mixed groups. The average value for the period 1963-1970 was $2.0(1.7-2.7)$ but the sample is far more

Table 9

Size of bull groups from 1963-1970 (summer period).

\begin{tabular}{lrrrr}
\hline Year & $\mathrm{n}$ & O.R. & Avg. & SD \\
\hline 1963 & 25 & $1-5$ & 2.4 & \pm 0.9 \\
1964 & 27 & $1-6$ & 2.7 & \pm 1.3 \\
1970 & 48 & $1-6$ & 2.6 & \pm 1.1 \\
1969 & 41 & $1-5$ & 1.7 & \pm 1.1 \\
1965 & 93 & $1-6$ & 1.7 & \pm 1.0 \\
1966 & 100 & $1-7$ & 1.9 & \pm 1.3 \\
1967 & 129 & $1-7$ & 2.0 & \pm 1.2 \\
1968 & 60 & $1-4$ & 1.7 & \pm 0.8 \\
$1963-1970$ & 523 & $1-7$ & 2.0 & \pm 1.2 \\
\hline
\end{tabular}




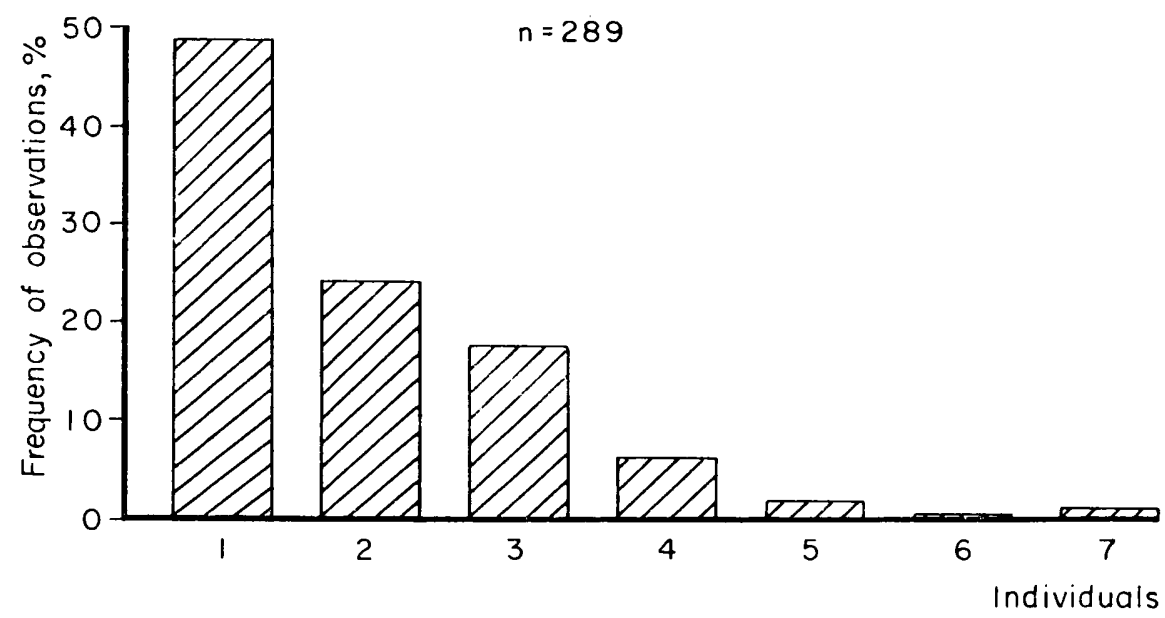

Fig. 16. Average size of bull groups from 1968-1970 (May-November).

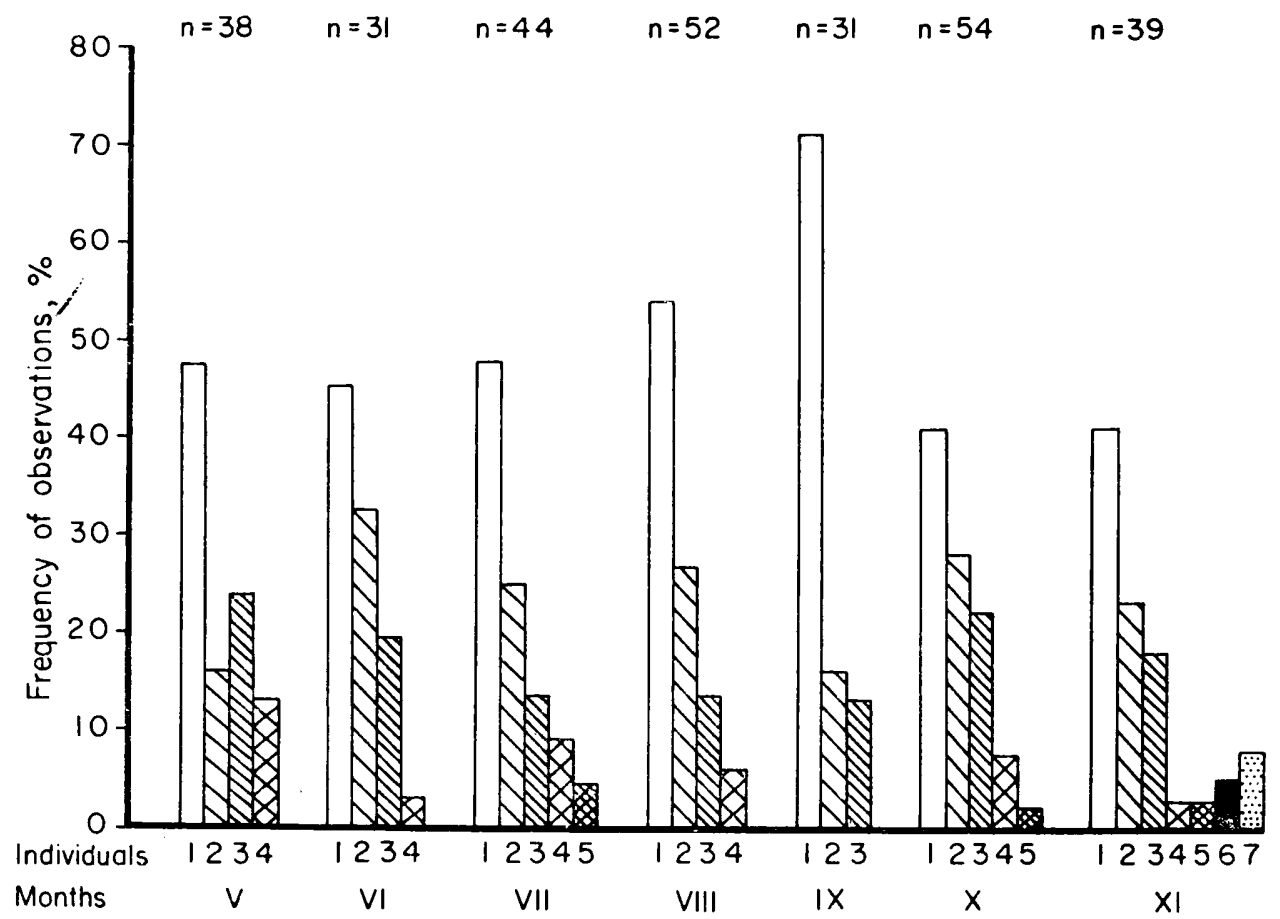

Fig. 17, Average size of bull groups from 1968-1970 depending on the season. 
balanced (SD - 1.2). As in the case of mixed groups no increase in group size is found in proportion to increase in population numbers. The maximum value found in 1964 was on an average 2.7 individuals in a group. Numbers in bull groups also varied within narrow limits of $1-7$ animals (Table 9 ).

During the period from 1968-1970 maximum frecuency of single bulls was observed $-48.4 \%(45.0-52.0 \%)$. Pairs of bulls formed $24.8 \%$ $(18.0-29.0)$, three bulls in a group $-17.5 \%(15.5-19.4 \%)$ of the total number of cases (Fig. 16). Thus groups containing in their composition $1-3$ bulls formed $90.7 \%$ of all the groups. A maximum number of 7 individuals was found in one group. As group size increases their frequency decreases (Fig. 16).

The size of bull groups depends on the season. In rutting months smaller groups are more often observed, contrary to what is found for mixed groups, this being connected with increase in frequency of single vulls. The highest percentage of single bulls over the course of three years (1968-1970) was found in September - 71\% of the total number of cases (Fig. 17). The increased frequency of single bulls during the rutting season can be explained by bull groups splitting up in order that some of the adult males may join mixed groups. Increase in the numbers of bull groups found in November is connected with bulls joining larger aggregations for the winter period (Fig. 17).

A connection was also found between size of bull groups and the age of males. Adult or old individuals were most often solitaries, while young $4-5$ year old bulls were usually encountered in larger groups.

\subsection{Winter Period}

As from the start of free breeding mixed groups were observed to combine into large aggregations in winter on the supplementary feedng sites. In the initial period of breeding the bison were supplied with food in two hay racks situated at a distance of $1 \mathrm{~km}$ from each other in forest sections 390 and 391 (Fig. 1). The bison congregating in this area formed one aggregation, the fre uently observed division of this aggregation into two parts being shortlived and of a transitional character. The numbers of this aggregation increased from year to year, reaching a maximum value of 97 animals in February 1968 (Fig. 18). Thus the numbers of this aggregation increased with growth of the bison population.

The second aggregation of bison was formed in forest section 422 at a distance of about $4 \mathrm{~km}$ from the preceding one. The specific character of this aggregation consisted in the fact that up to 1962 bulls only 
congregated there, being later joined by cows, but up to 1969 bulls formed the majority of this aggregation, which did not combine with the other aggregation. The size of this aggregation also increased with population growth, reaching the number of 60 animals in Frebruary 1971 (Fig. 18). As from the winter period of $1963 / 4$ certain of the

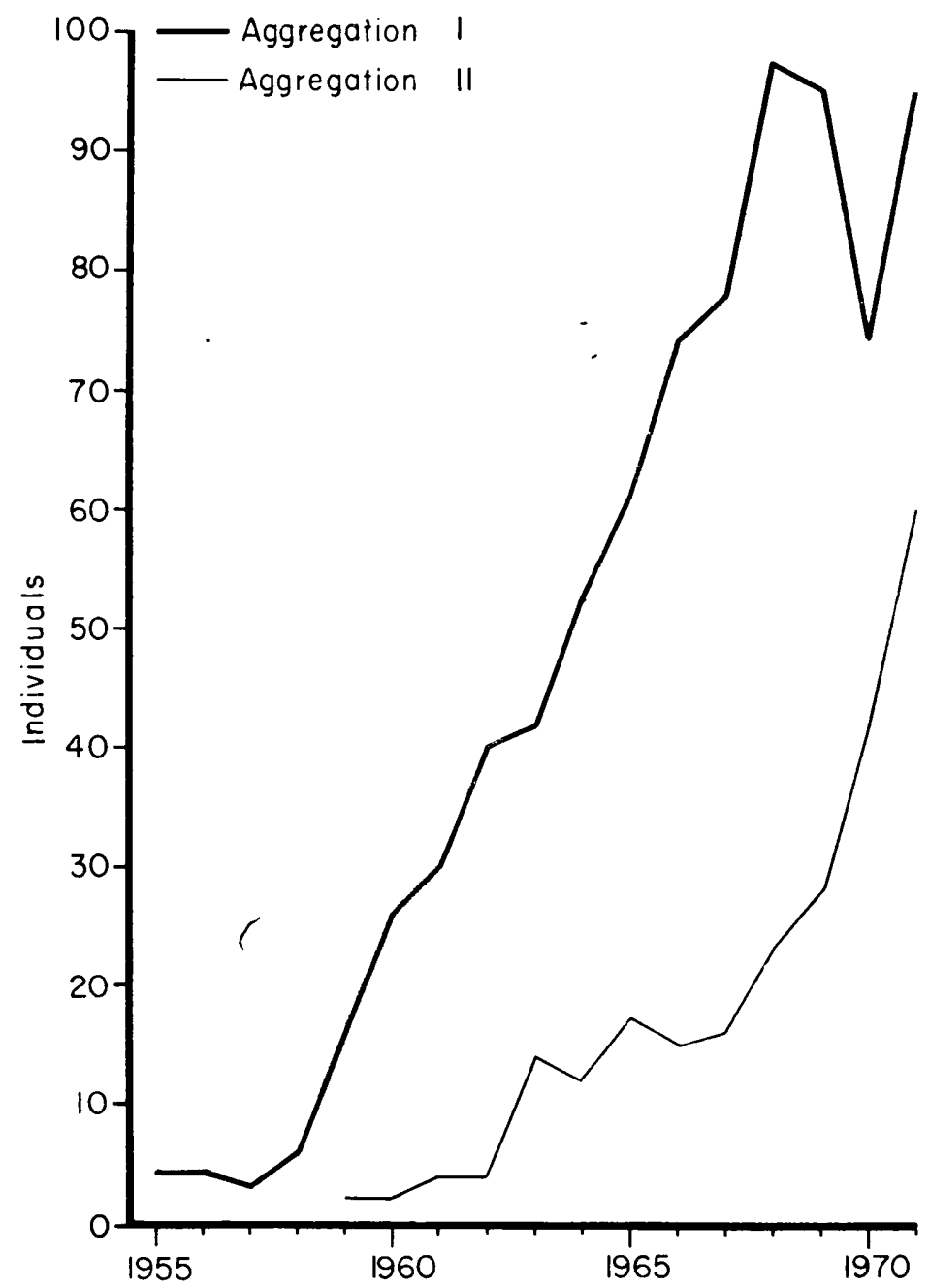

Fig. 18. Size of aggregations of bison during the winter period (Frebruary) from 1955-1971.

bison did not approach the two aggregations referred to above, remaining near different hay racks. These were bulls only. An additional third aggregation formed in forest section 306 only during the period 1969/70. 
The tendency of bulls to join larger aggregations for the winter period is far less distinct than in the other individuals in the population. Only some of the adult bulls $(10-50 \%)$ lived in mixed groups during this period. The remaining individuals $(50-90 \%)$ form from 5-9 separate aggregations during the winter period, but these groups are distinguished by a low degree of stability. The size of these groups saried from $1-15$ animals. The maximum number of 15 bulls in one group was found in February 1969, being twice as large as the maximum size of bull groups found during the summer period.

\section{DISCUSSION}

Indices defining population dynamics provide basic data on the state and progroses of the development of a population. In the case of large mammals such as bison, indices calculated for long-term cycles are reliable for defining population dynamics, and it is therefore essential to trace population dynamics from the historical aspect, especially as there are published data on the numbers of the natural population of European bison living in the Białowieża Primeval Forest during the 19 th century from 1809 to 1902 ( $\mathrm{K} \mathrm{a} \mathrm{r} \mathrm{cov}, 1903$ ) and from then until 1919 (W r óblewski, 1927). These statistics were based on an estimate of numbers made by tracking the animals, and therefore most certainly are burdened by the error involved in the tracking method (P u ce k at al., 1975). These data, however, form valuable and unique comparative material.

In analyzing dynamics of the number of bison living in the whole area of the Białowieża Primeval Forest in the 19th century a long phase of development, lasting 45 years, can be observed in the curve of population growth. Population numbers rose uninterruptedly from 1809 , when there were 350 bison, until 1857, when numbers reached a peak - 1898 animals. In subsequent years the numbers of bison decreased, expressed in decline in the growth curve, followed by a period of relative stabilization with fluctuations within limits of 400-750 animals (K a r cov, 1903; W r ó b l e w s ki, 1927).

Dynamics of the numbers of bison must, however, be considered in relation to the whole community of ungulates living in the Forest at that time. Variations in numbers of ungulates in the Białowieża Priineval Forest from 1890-1920 were reflected in intra- and interpopulation relations. The abrupt increase in the numbers of red deer, roe deer and fallow deer during the final phase of this period is remarkable (Fig. 19). Red deer in the Forest were completely exterminated in the 18 th century, and were not brought there again until 1864. The fallow 
deer, an alien species to the fauna of the Forest, was introduced at the same time. In 1907 the numbers of red deer were more than 5000, and fallow deer 1200. An even more abrupt rise in numbers is observed in the case of red deer, their maximum numbers being recorded in $1905-6000$ animals (Fig. 19). Variations in number of moose were similar to those of European bison up to 1900, but from that time on there was a continuous drop in its numbers. W róblewski (1927) considerad that the excessive density of deer brought about deterioration in the bison's food conditions and consequently stagnation in development of the bison population.

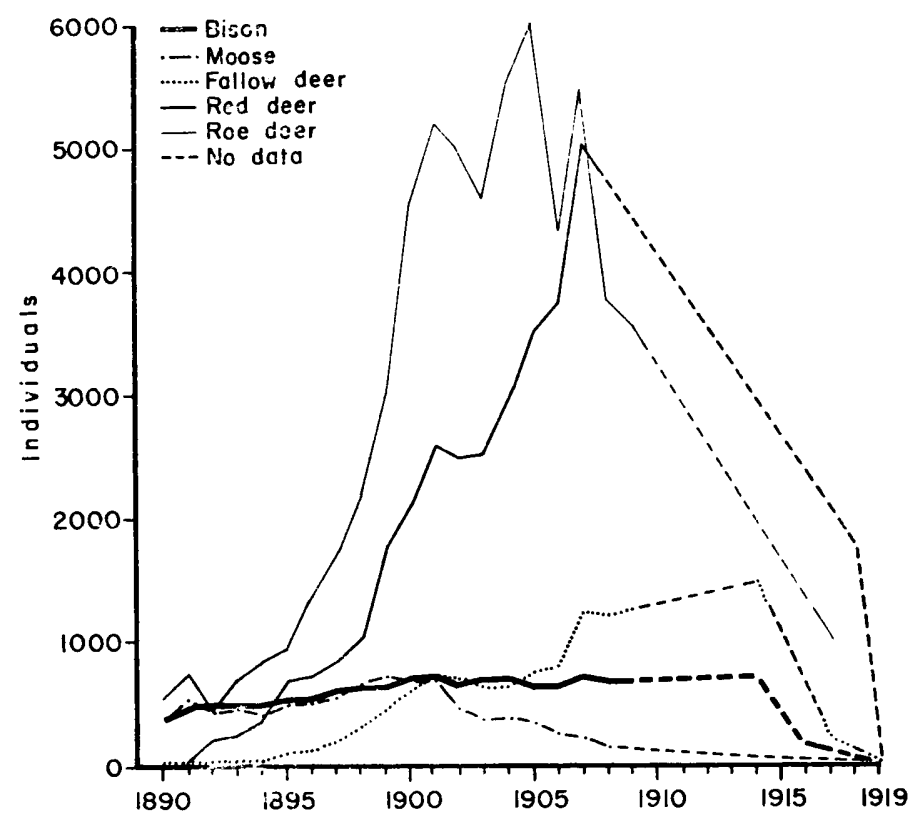

Fig. 19. Dynamics of numbers of bison in relation to variations in the numbers of ungulates in the Białowieża Primeval Forest from 1890-1919 (data after K a r cov, 1903; Wróblewski, 1927; Więcko, 1972).

Hostilities during World War I led to a sudden decrease in the numbers of ungulates in the Białowieża Primeval Forest. In 1919, when the last bison died, the history of the natural population of European bison in the Forest also ended.

Observations of the contemporary population of Białowieża bison cover a far shorter period and as yet relate only to its development phase. The growth of this population is of an exponential character. 
The reduction in herd increase from 1968-73 caused a decrease in population growth rate but did not inhibit its development. The level of herd increase (average 18.5\%) is higher than that which characterized the bison population living in the Białowieża Primeval Forest in the second half of the 19th century. For example it may be stated that increase in numbers of bison for a 20 year period (1873-1892) calculated on the basis of $\mathrm{B} u ̈ \mathrm{chner}$ 's data (1900) gave an average figure of $10.3 \%$. Reduction in recent years of the rate of increase in the restored herd coincides with the period when the structure of this herd was becoming closer to a natural one. Thus the high fecundity of the first period was typical of a population in growth phase.

Density and spatial structure are important elements of population structure and one essential to determine in order to ensure rational management of the bison population, since these factors influence the proper use of the habitat by these animals.

The given biotope preferences of bison affect their spatial structure and density. Using data from sample areas Borowski \& Kossak (1972) found that bison most decidedly prefer biotopes of mixed deciduous forest and deciduous forest. The author obtained similar results. It must, however, be remembered that in the case of bison the important role of feeding occurs in meadows and areas formed by tree felling such as clearings and cultivated crops (Fig. 10). Meadows are of even greater importance as a food source for American bison living in the wooded area of Elk Island National Park (S hacklet on, 1968), or Wind Cave National Park, where $71.7 \%$ of bull bison made use of meadows but only $19.2 \%$ of wooded areas (S hult, 1972). In Wood Buffalo National Park also the greatest concentration of bison was observed in meadows (Fulle r, 1961). These data indicate that habitat preferences form one of the factor's concentrating animals in the case of both European and American bison in certain regions.

The home range of bull bison was greater in both the western and also eastern part of the Forest than that of mixed groups, both during the first period of free breeding ( $\mathrm{K} \mathrm{r}$ a sins ki, 1967; K o r ock k in a, 1971 ), and also in subsequent years. Adult and usually solitary bulls visit not only cultivated fields near human settlements, but may even wander into the middle of villages (Photo 4). Density and also spatial structure were considered only for the summer period, since in winter these elements are distributed as the result of supplementary feeding, when density rises artificially, by even ten times as much. Similarly in the Caucasus Mts the density of the hybrids living there, in which there is a high percentage of bison blood, is 3-4 animals per 1000 ha 
in summer, but in winter may increase up to $40-50$ animals per 1000 ha (K a lug in, 1968, 1969).

No tendencies to migration into areas beyond the Forest proper have yet been observed in the bison population living in the western part of the Białowieża Primeval Forest, but in the eastern part of the Forest, although the numbers of bison there are three times smaller than in the western part, bulls have been found to migrate. Adult males migrated northwards from the boundary of the Forest to distances of $70-180 \mathrm{~km}$, and in one case even $350 \mathrm{~km}$ (K o r o č$\mathrm{k}$ in a, 1973). This may be due to the insufficient food supply in poor biotopes and also to the high density of other ungulates ( $\mathrm{K}$ o r o c k i n a, 1973). Auto-regulation of density by migration from overcrowded areas was found in moose by $\mathrm{T}$ o m e k (1973).

Both representatives of the genus Bison - the European and the American bison, form groups of similar type. Observation made over a three-year period on group composition of bison has made it possible to determine typical groups for the given season. In summer (from May to November) mixed groups, bull groups and single individuals occurred. The composition of the groups was not always complete and was typical of the given season.

When analyzing mixed groups during the summer period the high percentage of groups (about $50 \%$ ) in which adult bulls were observed outside the rutting season is remarkable. The presence of bulls in groups outside the rutting season has also been observed by Wróblewski (1927). The fact that some of these bulls are young individuals from 4-5 years old which, in J a c z e w ski's opinion (1958), do not as yet take part in reproduction, undoubtedly contributes to this phenomenon. The case is similar in respect to wild herds of American bison, when bulls under 5 years old do not yet take place in reproduction (Egerton, 1962). As in the case of European bison, three-year old and older bulls were found in mixed groups of American bison throughout the whole summer period (Shackleton, 1968). Increase in the number of bulls in groups during the rutting period was also observed there, but even during this period groups without adult bulls were found. Meagher (1973) also found that there were adult American bison bulls in mixed groups at all seasons of the year.

The observations presented above lead to the conclusion that in the genus Bison separation of the sexes is not observed outside the rutting season. In the majority of wild ruminants, e.g. red deer, separation of the sexes is very strict apart from the rutting season and adult stags 
join groups of hinds for a short time only, and only during the rutting season ( $\mathrm{D} z$ i ęg i e lew s ki, 1970).

During the winter period, particularly among mixed groups, large aggregations form which take the character of a loose gathering without any great cohesion. Final dispersion and formation of true groups takes place in spring, usually in the second half of April.

The author's observations show that family links exert an important influence on formation and shaping of different groups. W r ó ble w ski (1927) defines even the bison herd as a family group. In the case of American bison the bulls present in mixed groups neither dominate nor lead the groups even during the rutting period ( $\mathrm{Mc} \mathrm{Hugh}, 1958$; Shult, 1972; M e a gher, 1973). Bulls in mixed groups of European bison behave in the same way ( $\mathrm{Kr}$ a s in s ki, 1967).

Groups of European bison bulls both during the winter and summer period exhibit less cohesion than mixed groups, that is, they frequently disperse, while their composition and size alters. Similarly in American 'bison integration of bull groups is not as clearly expressed as in groups of cows, which exhibit greater "active solidarity" (Shult, 1972).

In free-living population of European and American bison the role of bull groups and single bulls, which are encountered during the rutting period independently of mixed groups, is not as yet sufficiently documented. McHugh (1972) considers that during the rut buil.; wander from group to group and thus exchange of bulls takes place. Egerton (1962) considers that bulls freely entering groups and leaving them cause increase in intensity of rutting behaviour.

Earlier authors were of the opinion that both in European (B o ja n u s, 1827) and American bison (S e to n, 1929; S o per, 1941; G a r r e tso n, 1938 - cited from Fuller, 1960) it was only old males which became solitaries, but $\mathrm{K}$ a r cov as early as 1903 emphasized that the tendency of bull bison to solitude cannot be attributed only to old age and weakness of bulls, since bulls in their full vigour often become solitaries. In the American bison population in Wood Buffalo National Park the decided majority in the bull group, i.e. $77 \%$, were solitaries. The age structure of these solitaries was estimated as follows: bulls 7 years old and older formed $34 \%$, subadult bulls $-65 \%$, while only $1 \%$ were $2-3$ year old bulls (F u l le r, 1960). In Wind Cave National Park solitaries formed $58.0 \%$ of all bulls observed ( $\mathrm{S} \mathrm{hult}$, 1972).

The tendency of bulls to lead a solitary way of life outside the group is thus a property of males of the genus Bison observed in both European and American bison.

More detailed information on hierarchy among bulls in the Białowieża Primeval Forest was supplied by observations from the first period of 
free breeding, when both the names and the age of the various bulls were known. Up to the age of 11 "Polel" maintained himself at the top of the group hierarchy, but when 12 years old was obliged to give way to the 6-year old "Poranek" and "Polas". This fact resulted in "Polel" not joining any mixed group the next year, and from that time onwards remaining a solitary. This confirmed later observations that bulls over 10 years old give place to younger bulls and their participation in reproduction is negligible.

The European bison is a gregarious animal, and this fact has been emphasized by every author who has had the opportunity of observing these animals living under natural conditions (B rincken, 1826; K a r cov, 1903; Wróblewski, 1927). Forest conditions are not favourable to the formation of large groups and therefore the size of groups of bison, typical inhabitants of wooded land, is not very large. is hacklet on (1968) has drawn attention to the connection between habitat conditions and size of groups of bison. American bison inhabiting the wooded areas of Elk Island National Park (Alberta) most often formed mixed groups composed of 5-20 animals, whereas bison in the prairie area of the National Bison Range (Montana) occurred in groups of 100-150 animals. The bison population living in a forest habitat in Wind Cave National Park also failed to form large groups (S h ult, 1972).

The first period of free breeding supplied interesting information on the way in which groups are formed. Up to 1958 all bison except bulls formed one group. When herd numbers rose to 18 in that year a tendency was observed to split into two as yet unstable groups. In 1961 the herd reached 44 in number, and then two typical mixed groups formed numbering from 13 to 16 individuals. Bulls lived a solitary life throughout the whole time apart from the rutting season. Group formation of this kind was typical of the bison population in the Białowieża Primeval Forest.

The observations made from 1968-1970 show that small and medium mixed groups predominate in the bison population in summer. About $90 \%$ of all mixed groups was formed by groups not exceeding 20 individuals.

The size of bison groups in the Białowieża Primeval Forest during the 19th century was also far from large and according to $\mathrm{Bojanus}$ (1827) was from 10-40 animals, $\mathrm{Kulag}$ in (1919) - from 5 to 13 animals and W r ó ble w s ki (1927) defined their size as 7-18 animals. All these authors noted, however, that in certain periods group numbers may rise to 50 and over. $\mathrm{K} \mathrm{a} \mathrm{r} \mathrm{c} \mathrm{ov} \mathrm{(1903)} \mathrm{stated} \mathrm{that} \mathrm{during} \mathrm{the} \mathrm{sum-}$ mer period the largest groups reached numbers of 15-18 animals. He 
also gave the valuable information that during the winter period the smaller groups combined near the feeding places into larger aggregations, as is the case at present. A tendency to form large aggregations during the winter period was therefore found in European bison as early as the 19th century, but it must be remembered that even then these animals were given supplementary food in winter. It is difficult to arrive at an unquivocal decision as to whether this phenomenon is of an original character and is a characteristic of the species. or a secondary phenomenon formed as the result of supplementary feeding over a long period of years, since there is no information on the behaviour of completely wild bison. Contemporary observations show that formation of large aggregations in winter cannot be explained solely by the presence of permanent feeding places or by supplementary feeding as a whole.

The average group size in the summer period has not increased together with increase in numbers of the bison population in the Bialowieża Primeval Forest, whereas size of aggregations during the winter period has risen with increase in population numbers.

Supplementary feeding in winter is the factor which exerts the strongest anthropogenic pressure on the bison population in the Bialowieża Primeval Forest. Information on the last natural herd in the 19 th century also relates to a population receiving supplementary feeding during the winter. It is difficult to envisage how the restored population would have developed if winter supplementary feeding had not been practised from the start, or if it had been interrupted, for instance when supplementary winter feeding ceased it did not cause increase in mortality in winter among the bison population in the Yellowstone National Park (M e a g h e r, 1973). This cannot, however, be considered as grounds for taking a similar decision in respect of the Białowieża Primeval Forest, on account of the different natural and economic conditions there.

The purpose of supplementary feeding is inter alia to reduce the degree to which European bison unfavourably affect tree stands. Lack of supplementary food in winter, or even its temporary suspension, would cause an abrupt increase in damage done to tree stands ( $\mathrm{B}$ or owski, 1971). By means of supplying supplementary food it is possible to limit the amount of damage done as the result of the amount of food requirements, although it is difficult to eliminate barking of trees altogether, if this takes place as the result of deficiencies in quality of food, of certain micro-elements, vitamins etc.

Some comparisons have been made above between the European bison population living in the Białowieża Primeval Forest and some of the 
American bison populations living in Canada and the United States. Only the large bison population numbering about 15,000 animals living in Wood Buffalo National Park in Canada can be considered as a fully natural population, in that it differs from the remainder in respect of numbers, area occupied and habitat conditions. Increase in this population is $9-10 \%$ annually, but the high natural mortality, chiefly among calves, results in increase being ade ${ }^{\sim}$ uate in relation to losses and the population maintaining itself in a state of balance (Fuller, 1961).

The bison population in Yellowstone National Park, numbering over 500 individuals, would appear to be most similar to the bison population in the Białowieża Primeval Forest, on account of living conditions and similarity of structure. The low percentage of calves - $11 \%$ (M e a g h e r, 1973 ) in this population is remarkable, and is like the case with European bison, where calves formed $15 \%$ of the population.

The comparisons of ecological properties of European and American bison made in this paper point to far-reaching similarities and may form support for Bohlken's taxonomic proposal (1967) to unite European and American bison into one species, with four subspecies.

The present paper initiated studies undertaken not long ago on the ecology of the European bison. These studies need supplementing, primariıy in respect to questions of social organization and behaviour. Similar studies in other populations, for instance those living under different conditions in the Bieszczady Mountains, would also be necessary and useful.

Acknowledgements: My thanks are due to Professor Zdzisław Pucek for his assistance and valued advice during the whole period of these studies and elaboration of results, and his criticism of the first draft of this paper. I am also indebted to the Management of the Białowieża National Park for making it possible for me to carry out these studies and to the staff of the European Bison Breedin's, Centre at Bialowieża, whose observations have contributed to so great a degree to collection of documentary material. Dr. Terry L. Erwin kindly reviewed the English text.

\section{REFERENCES}

1. Banfield A. W. F. \& Novakowski N. S., 1960: The survival of the Wood Bison (Bison bonasus athabascae $\mathrm{Rhoads}$ ) in the Northwest Territories. Nat. Hist. Papers Nat. Mus. Canada, 8: 1-6.

2. Bohlken H., 1967: Beitrag zur Systematik der rezenten Formen der Gattung Bison H. S m it h, 1827. Z. zool. Syst. Evolutionsforschung, 5, 1: 54-110.

3. Bojanus H. L., 1827: De Uro nostrate eiusque sceleto commentatio. Nova Acta phys. Acad. Caes. Leopold.-Carol. Nat. Curios., 23, 2: 413-478. Bonnae.

4. Borowski S., 1971: Intensywność żerowania żubrów i zwierzyny płowej w Puszczy Białowieskiej. Postępy restytucji żubra, 3 (Msc).

5. Borowski S. \& Kossak S., 1972: The natural food preferences of the 
European bison in seasons free of snow cover. Acta theriol., 17, 13: 151-169.

6. B r incken J., 1926: Memoire Descriptif sur la Foret Imperiale de Białowieża, en Lithuanie. N. Gücksberg: 1-127. Varsovie.

7. B üchner E., 1900: Powolne wymieranie żubra w Puszczy Białowieskiej. Eowiec pol., 7, 19: 2-4, 20: 2-3, 21: 1-2, 22: 2-3, 23: 3-4.

8. Dzięgielewski S., 1970: Jeleń. Państw. Wyd. Roln. i Leśn.: 1-298. Warszawa.

9. Egerton P. J. M., 1962: The cow-calf relationship and rutting behavior in the American bison. University of Alberta: Master's thesis for the Department of Zoology, 1-155.

10. F a li ński J. B., 1968: Położenie, granice i nazewnictwo fizjograficzne Puszczy. [In: „Park Narodowy w Puszczy Białowieskiej«, ed.: J. B. Faliński]. Państw. Wyd. Roln. i Leśn.: 13-24. Warszawa.

11. Fulder W. A., 1959: The horns and teeth as indicators of age in bison. J. Wildl. Manage., 23: 342-344.

12. Fulle r W. A., 1960: Behaviour and social organization of the wild bison of Wood Buffalo National Park, Canad. Arctic, 13, 1: 1-19.

13. Fuller W. A., 1961: The ecology and management of the American bison. La Terre et la Vie, 108, 2-3: 286-304.

14. J a czewski Z., 1958: Reproduction of the European bison, Bison bonasus (L.) in reserves. Acta theriol., 1, 9: 333-376.

15. Ka lug in S. G., 1968: Vosstanovlenie zubra na severozapadnom Kavkaze. Tr. Kavkaz. gos. zap., 10: 3-94.

16. Ka lug in S. G., 1969: Stan populacji „górskich" żubrów w rejonie północno-zachodniego Kaukazu. Postępy restytucji żubra, 2: 254-257.

17. Karcov G., 1903: Belovežskaja Pušč. Artist. Zaved. A. F. Marksa: 1-414. S.-Petersburg.

18. Koročkina L. N., 1969: O sozdanii volnogo stada belovežskich zubrov v Belovežskoj Pušce. Postępy restytucji żubra, 2: 177-192.

19. Koročkina L. N., 1971: Niektóre zagadnienia z zakresu reaklimatyzacji żubrów w radzieckiej części Puszczy Białawieskiej. Postępy restytucji żubra, 3 (Msc).

20. Kor očkina L. N., 1973: Rajon obitanija i stacjalnoe razmešcenie zubrov v Belowežskoj Pušče. Belovežskaja Pušč, 7: 148-164.

21. Krasiński Z., 1967: Free living European bison. Acta theriol,, 12, 29: $391-405$.

22. Krasiński Z., 1968: Żubr w Puszczy. [In „Park Narodowy w Puszczy Białowieskiej«, ed. J. B. Faliński]. Państw. Wyd. Roln. i Leśne: 267-272. Warszawa.

23. Krasiński Z. \& Raczyński J., 1967: The reproduction biology of the European bison living in reserves and freedom. Acta theriol. 12, 29: 407-444.

24. Ku lag in N. M., 1919: Zubry Belovežskoj Pušči. Izd. Mosk. Naučn. Inst.: 1-166. Moskva.

25. $\mathrm{M} \mathrm{cHugh} \mathrm{T.} \mathrm{S.,} \mathrm{1958:} \mathrm{Social} \mathrm{behaviour} \mathrm{of} \mathrm{the} \mathrm{American} \mathrm{buffalo} \mathrm{(Bison} \mathrm{bison}$ bison). Zoologica, 43, 1: 1-40.

26. McHugh T., 1972: The time of the buffalo. A. A. Knopf: 1-339. New York.

27. M e a gher M. M., 1973: The bison of Yellowstone National Park. National Park Service Scientific Monograph Series, 1: 1-161. 
23. M $\mathrm{i} ¥ \mathrm{k}$ ow ski L., 1969: $\mathrm{Z}$ doświadczeń nad inwentaryzacją zwierzyny w Puszczy Białowieskiej. Eowiec pol., 22 (1361): 4-5.

29. Olszewski J. L., 1968: Klimat Puszczy. [In »Park Narodowy w Puszczy Białowieskiej«, ed. J. B. Faliński]. Państw. Wyd. Roln. i Leśn.: 39-46. Warszawa.

30. Pucek Z., 1967: The most important problems for further studies on European bison. Acta theriol., 12, 35: 495-501.

31. Pucek Z., Bobek B., Eabudzki L., Miłkowski L., Morow K. \& $\mathrm{T} \circ \mathrm{mek}$ A., 1975: Estimates of density and number of Ungulates. [In: "The role of large herbivore mammals in woodland ecosystems", Grodziński W. i Pucek Z., Eds]. Polish ecol. stud., 1, 2: 121-135.

32. Romanowski V. P. \& Kočanovski S. B., 1971: Przedsięwzięcia w zakresie ulepszania warunków bytowania żubrów w Puszczy Białowieskiej. Postępy resty.tucji żubra, 3 (Msc).

33. Schwerdtfeger F., 1968: Demökologie. Verlag Paul Parey.: 5-448. Hamburg, Berlin.

34. Shackleton D. M., 1968: Comparative aspects of social organization of American bison. The University of Western Ontario: 1-67. London, Canada.

35. Shult M. J., 1972: American bison behavior patterns at Wind Cave National Park. Iowa State University, Ph. D. theses, Zoology: 1-178.

36. Szafer W., 1919: Z Puszczy Białowieskiej-wrażenia z wycieczki odbytej w kwietniu 1919. Przewodnik Kólek Roln. Warszawa.

37. Tom e k A., 1973: Badania nad ekologia losia (Alces alces L.) w Polsce i jego znaczenie $w$ ochronie lasu. Ph. D. Theses. Agricultural University, Cracov, (MSC).

38. W i ęcko E., 1972: Puszcza Białowieska. Państw. Wyd. Nauk.: 1-193. Warszawa.

39. Wróblewski K., 1927: Żubr Puszczy Bialowieskiej. Wyd. Polskie: 1-232, Poznań.

40. Ża biński J., (Ed.), 1976: European bison pedigree book 1973. Polish. Sci. Publ.: 179-229. Warszawa.

Accepted, August 17, 1977.

Zbigniew KRASIŃSKI

\section{DYNAMIKA I STRUKTURA POPULACJI ŻUBRÓW W PUSZCZY BIAEOWIESKIEJ}

\section{Streszczenie}

Praca omawia dynamike populacji, strukturę płciową i wiekową, skład i wielkość grup, zagęszczenie, strukturę przestrzenną wolnej populacji żubrów w Puszczy Białowieskiej.

W 1973 w zachodniej części Puszczy Białowieskiej (PRL) stado żubrów osiągnęlo liczebność 253 (112, 141) sztuk (Tabela 1) i lącznie z drugim wolnym stadem we wschodniej części Puszczy Białowieskiej (BSRR) osiągnęło liczebność 335 żubrón. 
Była to zaledwie połowa stanu naturalnej populacji żubrów żyjącej w Puszczy pod koniec XIX wieku (Ryc. 7).

W pracy wykorzystano materiały od początku hodowli wolnej, to jest od 1952 roku do końca 1973 roku. Szczególową analizą objęto lata 1968-1970, kiedy to wprowadzono jednolity system obserwacji. W okresie tym przeprowadzono 2400 obserwacji w dwóch wyraźnie różniących się i oddzielnie opracowanych okresach, nazwanych umownie letnim (maj-listopad) i zimowym (grudzień-kwiecień).

W zimie żubry były dokarmiane sianem przez srednio 163 dni co niewątpliwie zakłócało naturalną strukturę i organizację populacji w tym okresie.

Zubry tworzą ugrupowania dwóch typów: (1) grupy mieszane zawierające w swym składzie zwierzęta obu płci, w różnych klasach wiekowych, oraz (2) grupy byków.

W okresie 1968-1973 struktura populacji żubrów charakteryzowała się znaczną stabilnością, krowy dorosłe (4 letnie i starsze) stanowiły od $30,6 \%$ do $36,5 \%$, byki dorosłe (4 letnie $i$ starsze) stanowiły od $23,9 \%$ do $26,1 \%$, młodziez $2-3$ letnia od $25,4 \%$ do $27,4 \%$ i cielęta od $14.2 \%$ do $16,1 \%$ populacji (Ryc. 2 ).

Fakt ten wskazuje, że populacja żubrów w Puszczy Białowieskiej zmierza do wykształcenia struktury będącej jej naturalną właściwością. Strukturę populacji w ostatnim badanym roku (1973) obrazuje piramida wieku (Ryc. 3).

W okresie 1960-1973 współczynnik urodzeń wynosił średnio 18,5\% (Tabela 2). Współczynnik płodności w latach 1958-1966 równal się średnio 70,3\% po czym (1967-1973) uległ obniżeniu do 54,1\% (Tabela 3).

Stosunek płci przy urodzeniu nie odbiegal istotnie od proporcji 1:1 przy 316 (161, 155) urodzonych cielętach (Tabela 1). Współczynnik śmiertelności w latach 1959-1973 wynosil średnio 3\% (Tabela 4). Obserwowano istotnie większą śmiertelność samców $(69,4 \%$ całej śmiertelności) w porównaniu z samicami. Najwyższą śmiertelność notowano $w$ grupie cieląt do jednego roku $-22,6 \%$, najniższą $w$ najstarszej klasie wieku - 2,1\% (Ryc. 5).

Po fazie początkowego wzrostu, krzywa dynamiki liczebności przybrała typ wykładniczy $z$ zaznaczoną $w$ ostatnich latach tendencją do przechodzenia $w$ faze wzrostu zwolnionego (Ryc. 6).

Areał bytowania powiększal się wraz ze wzrostem populacji żubrów do 1966 roku. W następnych latach ze wzrostem liczebności wzrastało zarówno zagęszczenie globalne $(3,4$ sztuki na 1000 ha), jak i zagęszczenie rzeczywiste (12 sztuk na 1000 ha).

Rozmieszczenie w przestrzeni grup mieszanych jest bardziej skupiskowe (Ryc. 8) niż grup byków, które wykazują większą dyspersję na całym obszarze Puszczy (Ryc. 9).

Na rozmieszczenie grup żubrów w okresie letnim wywierają wplyw preferencje siedliskowe. Najczęściej spotyka się żubry w lesie mieszanym $(23,7 \%$ ogółu spotkań) i w lesie liściastym (18,5\%), najmniej penetrowane są bory, na które przypadało $2,1 \%$ ogółu spotkań oraz olsy $(9 \%)$. Żubry często żerują na terenie otwartym - zrębach, łąkach, polach uprawnych (46,7\% ogółu spotkań) (Ryc. 10).

Skład grup mieszanych ulega zmianom w różnych sezonach roku. W okresie rui wzrastała ilość grup zawierających $w$ swym składzie dorosłe byki. Stanowią one wtedy $74,7 \%-86,8 \%$ wszystkich grup mieszanych, podczas gdy w okresie przedrujowym - tylko 54,8\% (Ryc. 11). W okresie rui wzrasta dwukrotnie ilośc dorosłych byków w grupach mieszanych (Tabela 6). Udział cieląt $w$ grupie wzrasta od maja $(4 \%)$ do lipca a następnie utrzymuje się na podobnym poziomie (ponad $15 \%$ grupy) (Ryc. 12). Ponad $60 \%$ byków, średnio, w ciągu całego sezonu letniego występuje w grupie mieszanej pojedynczo (Ryc. 13). W okresie rujowym (sierpień, wrzesień) 
wzrasta procentowy udział dorosłych byków $w$ grupach mieszanych (Ryc. 14). W tym okresie obserwuje się wzrost frekwencji bykow - samotników (Fyc. 17), co nasuwa wniosek o współzależności tych faktów. W okresie zimowym tworzą się duże ugrupowania powstające $\mathrm{z}$ połączenia się wielu grup mieszanych. W największym ugrupowaniu począwszy od 1968 roku, gromadzilo się około 100 żubrów. Wielkość ugrupowań mieszanych w okresie zimowym rosła systematycznie, wraz ze wzrostem liczebności populacji (Ryc. 18). W okresie tym od $55,5 \%$ do $89,4 \%$ dorosłych byków przebywało poza ugrupowaniami mieszanymi tworząc 5-9 oddzielnych ugrupowań (Tabela 7).

Srednia wielkość grupy mieszanej w okresie letnim w latach 1963-1970 wynosiła 11,9 sztuk. Nie obserwowano powiększania się wielkości grup ze wzrostem populacji (Tabela 8). Stwierdzono najwyższą frekwencję grup liczących do 10 osobników $(28,8 \%-33,5 \%)$, Ryc. 15. Srednie wielkości grup żubrów w okresie rujowym (sierpień, wrzesień) były istotnie wyższe niż $w$ czerwcu $(0,02<\mathrm{P}<0,05)$ i październiku-listopadzie $(\mathrm{P}<0,02)$. Grupy byków w okresie letnim (1963-1970) liczyły od 1-7 sztuk, średnio 2,0 sztuki (Tabela 9 ). Około $50 \%$ byków chodziło pojedynczo, grupy składające się z 1-3 byków stanowily około $90 \%$ ogólu grup byków (Ryc. 16).

Stwierdzono stosunkowo wyrównany rozkład upadków śmiertelnych $w$ ciągu całego roku (Tabela 5), co świadczy, iż zima nie stanowi dla żubrów krytycznego okresu. Z przyczyn śmiertelności najwyższy procent upadków stanowiły urazy mechaniczne - 32,8\%, przy czym 20,9\% zostało spowodowane przez same żubry, a $11,9 \%$ przypadków stanowiły urazy powstałe na innym tle.

W dyskusji przeprowadzono porównanie uzyskanych wyników z danymi na temat ekologii ostatniej naturalnej populacji żubrów jaka bytowała w Puszczy Białowieskiej przed I wojną światową. Stwierdzno, że obecnie obserwuje się wyższy poziom przyrostu stada od notowanego $w$ tamtej populacji. W obu okresach wielkość grup była podobna. Obserwowano też tendencję do tworzenia dużych ugrupowań o okresie zimowym w pobliżu miejsc dokarmiania.

Dla prawidłowego kierowania dalszą restytucją żubra konieczne jest uwzględnienie liczebności innych komponentów zespolu kopytnych Puszczy Białowieskiej. Wynika to z losu kopytnych, bytujących w Puszczy w XIX wieku (Ryc. 19).

Interesujące okazały się porównania niektórych aspektów ekologii żubra $z$ bizonem. Stwierdzone duże ekologiczne podobieństwa mogą być poparciem dla tezý Bohlkena (1967) o polączeniu żubra i bizona $w$ jeden gatunek $z$ czterema podgatunkami.

Uzyskane $w$ tych badaniach wyniki powinny być pomocne $w$ opracowaniu metod racjonalnego gospodarowania wolną populacją żubra w Puszczy Białowieskiej. 


\section{EXPLANATION OF PLATES I-II}

Plate I.

Photo 1. Adult bull feeding in a meadow inside wooded land during the earlyy winter. Obtaining food from under snow plays only a minimal role in the feeding habits of bison.

Photo 2. Mixed group feeding in a meadow by the River Eutownia.

Plate II.

Photo 3. Mixed group during the autumn period.

Photo 4. Adult bull, which had lived in fields in the autumn of 1974, moved too the centre of Bialowieża near the Greek Orthodox church at the beginning off January 1975. 

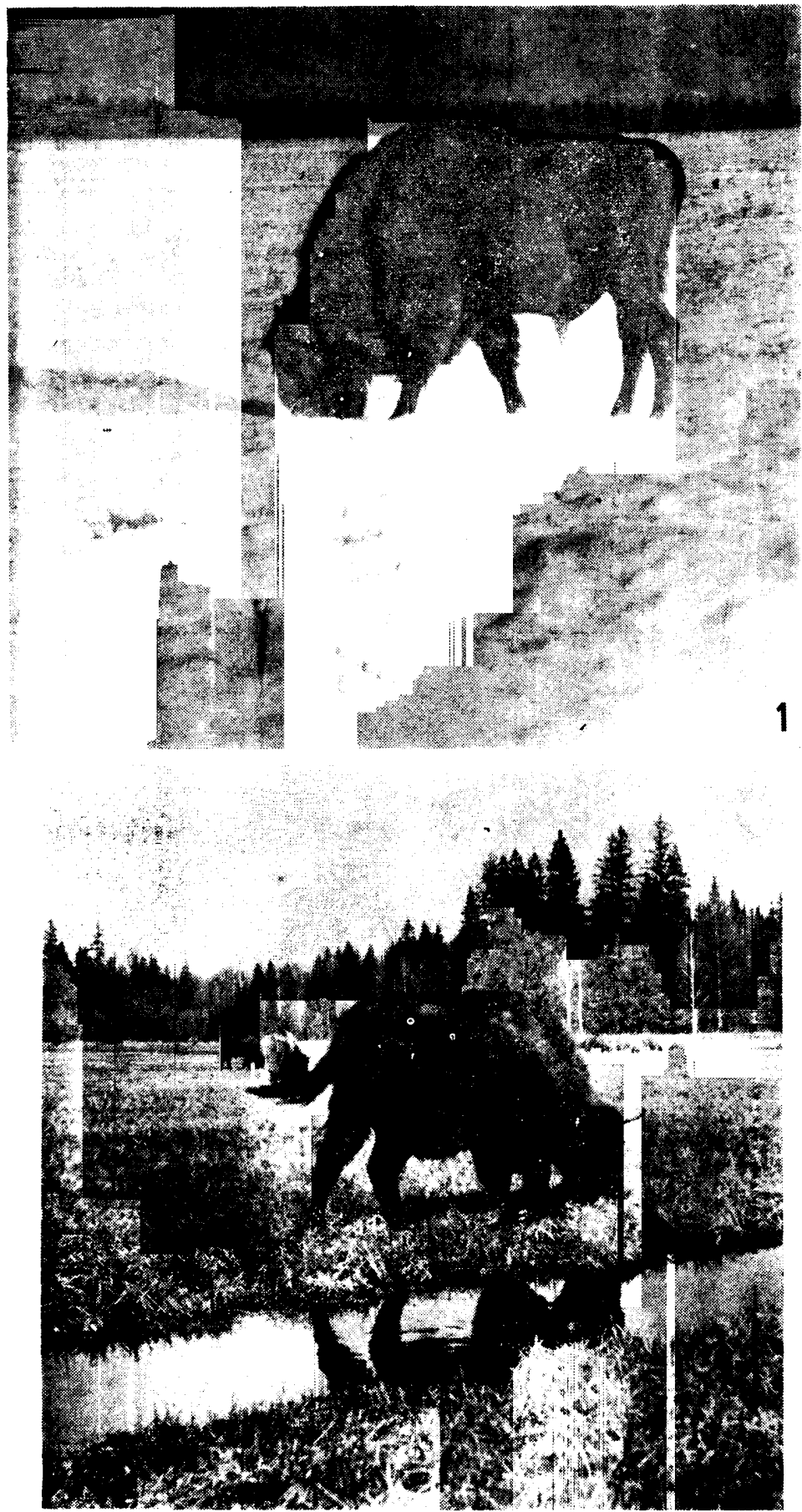

